\title{
Mapa geológico do cenozoico da região da bacia de Volta Redonda (RJ, segmento central do Rifte Continental do Sudeste do Brasil): identificação de novos grabens e ocorrências descontínuas, e caracterização de estágios tectonossedimentares
}

Geological map of the Cenozoic of Volta Redonda Basin region (Rio de Janeiro State, Central Segment of the Continental Rift of Southeastern Brazil): identification of new grabens and discontinuous occurrences, and characterization of tectonosedimentary stages

\author{
André Pires Negrão, ${ }^{1,2 *}$, Renato Rodriguez Cabral Ramos ${ }^{3}$, \\ Claudio Limeira Mello², Marcel de Souza Romero Sanson ${ }^{4}$
}

\begin{abstract}
RESUMO: $\mathrm{O}$ presente trabalho traz os resultados inéditos da cartografia e análises tectonossedimentares do cenozoico da regiáo da bacia de Volta Redonda, inserida no segmento central do Rifte Continental do Sudeste do Brasil (RCSB). Distribuídos na direção NE-SW, foram reconhecidos três depocentros paleogênicos (grabens de Colônia Santo Antônio, Dorândia, Casa de Pedra - mais importante, por seu registro sedimentar e vulcânico) e diversas ocorrências paleogênicas descontínuas (áreas de Belmonte, Jardim Amália, Cafundó, Vargem Alegre), além de dois importantes grabens quaternários (grabens do Rio do Bananal e da Usina). O preenchimento paleogênico foi relacionado a três estágios tectônicos: fase Pré-Rifte, vinculada à deposição da Formaçăo Ribeirão dos Quatis (fluvial); fase Rifte I (principal), a que se relaciona a Formaçáo Resende (sistemas fluviais e leques aluviais associados a bordas de falhas principais, além de vulcanismo basanítico intercalado); fase Rifte II (final), a que se relacionam os depósitos da Formação Pinheiral (fluvial), responsáveis pela colmatação dos depocentros paleogênicos. Acumulaçôes significativas de depósitos aluviais recentes vinculam-se ao preenchimento dos grabens quaternários. A atual configuraçấo da regiấo da bacia de Volta Redonda resulta da geração de diversas estruturas rúpteis vinculadas a sua abertura e deformação neotectônica. Desta forma, este segmento do RCSB é representado por um mosaico depocentros e ocorrências paleogênicas descon-
\end{abstract}

${ }^{1}$ Petrobras, Centro de Pesquisas e Desenvolvimento, Gerência de Sedimentologia e Estratigrafia, Rio de Janeiro (RJ), Brasil, E-mail: andrenegrao.geo@gmail.com ${ }^{2}$ Departamento de Geologia, Instituto de Geociências, Universidade Federal do Rio de Janeiro - UFRJ, Rio de Janeiro (RJ), Brasil. E-mail: limeira@geologia.ufrj.br ${ }^{3}$ Departamento de Geologia e Paleontologia, Museu Nacional, Universidade Federal do Rio de Janeiro - UFRJ, Rio de Janeiro (RJ), Brasil. E-mail: rramos@mn.ufrj.br ${ }^{4}$ Petrobras, Unidade de Operações da Bacia de Campos, Exploração, Macaé (RJ), Brasil. E-mail: sanson@petrobras.com.br *Autor correspondente

Manuscrito ID: 30262. Recebido em: 18/03/2015. Aprovado em: 04/05/2015. 
tínuas significativamente compartimentadas por deformação netectônica, além de depocentros quaternários, vinculados principalmente ao último evento distensivo, de idade holocênica. Da identificação e caracterização destas feiçốes, a regiáo da bacia de Volta Redonda passa a apresentar um novo quadro de distribuiçáo do registro cenozoico, com dimensóes em torno de $40 \mathrm{~km}$ na direçâo NE-SW e $10 \mathrm{~km}$ na direçâo NW-SE.

PALAVRAS-CHAVE: Cartografia Geológica; Volta Redonda; Tectônica; Sedimentação.

\section{INTRODUÇÃO}

Os primeiros trabalhos de mapeamento na bacia de Volta Redonda foram publicados por Amador \& Castro (1976), que elaboraram os estudos pioneiros sobre seu preenchimento, identificando depósitos correlacionáveis aos da Formação Resende na bacia homônima.

Melo et al. (1983) publicaram um mapa geológico mais completo, definindo duas áreas de principal acúmulo sedimentar paleogênico, sendo a mais importante definida como área de Casa de Pedra, incluindo derrames de rochas vulcânicas basaníticas intercalados aos sedimentos, posteriormente definida por Riccomini (1989) como graben de Casa de Pedra. Na regiáo compreendida entre Barra Mansa e Volta Redonda, em faixas marginais ao norte e ao sul da planície do rio Paraíba do Sul, foram registradas ocorrências isoladas de depósitos paleogênicos em topos de colinas.

Sanson et al. (2006), com base principalmente em levantamentos no graben de Casa de Pedra, reconheceram e mapearam três unidades sedimentares paleogênicas: formaçōes Ribeirão dos Quatis, Resende — correlacionáveis a unidades presentes na bacia de Resende, conforme definição de Ramos et al. (2006) - e Pinheiral, esta última reconhecida como unidade distinta, de forma inédita. Foram ainda incluídas em seu mapa outras ocorrências de rochas vulcânicas basaníticas.

Análises estruturais detalhadas e ampla discussão sobre a evoluçấo tectônica cenozoica da regiáo da bacia de Volta Redonda encontram-se disponíveis em Negrão (2014) e estâo sendo preparadas para publicação em periódico.

Até o momento, os únicos dados de subsuperfície disponíveis para a regiáo da bacia de Volta Redonda foram elaborados por Padilha e Vitorello (1992). Estes autores, através de levantamentos audiomagnetotelúricos no graben de Casa de Pedra, indicaram uma espessura sedimentar máxima em torno de $120 \mathrm{~m}$, em local próximo a borda norte desta área.

O estudo aqui apresentado propóe um novo mapa das ocorrências cenozoicas na região de Volta Redonda a partir de análises de modelos digitais de elevação e imagens de satélite, e de levantamentos de campo. São reconhecidas outras duas importantes áreas de acúmulo sedimentar paleogênico, além daquelas já identificadas e documentadas nos trabalhos anteriores. Estas áreas estáo situadas ao leste e ao oeste do graben of paleogenic dpocenters and discontinuous occurrences significantly compartmentalized by recent deformation, and quaternary depocenters, mainly linked to the Holocene extension event. The identification and characterization of these feautures, brings a new arrangement of cenozoic record in the region of the Volta Redonda basin, measuring around $40 \mathrm{~km}$ in the NE-SW and $10 \mathrm{~km}$ in the NW-SE direction.

KEYWORDS: Geological Cartography; Volta Redonda; Tectonic; Sedimentation.

de Casa de Pedra e são aqui definidas, respectivamente, como graben de Dorândia e graben de Colônia Santo Antônio. As semelhanças no preenchimento sedimentar e nos estilos estruturais constatados nestas áreas, além da proximidade relativa com aquelas já documentadas na literatura, permitiram relacionar geneticamente tais regiốes com a evoluçấo da bacia de Volta Redonda. Também é proposta a redefinição dos limites do graben de Casa de Pedra e das demais ocorrências sedimentares cenozoicas da regiáo estudada.

\section{ÁREA DE ESTUDO}

A área do presente estudo localiza-se na regiáo oeste do estado do Rio de Janeiro, estando inserida no médio vale do rio Paraíba do Sul, abrangendo os municípios de Volta Redonda, Barra Mansa, Porto Real, Pinheiral, Piraí e Barra do Piraí (Fig. 1). As coordenadas geográficas que limitam a área de estudo correspondem aos paralelos $22^{\circ} 25^{\prime} 00^{\prime \prime} \mathrm{e}$ $22^{\circ} 40^{\prime} 00^{\prime \prime}$ sul e meridianos $44^{\circ} 20^{\prime} 00^{\prime \prime}$ e $43^{\circ} 50^{\prime} 00^{\prime \prime}$ oeste.

A principal via de acesso à área de estudo é a Rodovia Presidente Dutra (BR-116), que liga o Rio de Janeiro a São Paulo. A partir desta rodovia, pode-se alcançar a região da bacia de Volta Redonda através das estradas de acesso direto à cidade de Volta Redonda (RJ-494, BR-393 e Rodovia dos Metalúrgicos) e pela estrada para Volta Redonda via Pinheiral.

\section{CONTEXTO GEOLÓGICO}

A bacia de Volta Redonda está inserida no contexto do Rift Continental do Sudeste do Brasil (RCSB) (Riccomini 1989), em seu segmento central. $\mathrm{O}$ embasamento da bacia, assim como os demais domínios do RCSB, desenvolve-se sobre terrenos proterozoicos/eopaleozoicos da Faixa Ribeira, constituído por complexos ortoderivados paleoproterozoicos, complexos paragnáissicos neoproterozoicos e suítes intrusivas neoproterozoicas/eopaleozoicas, inserido no domínio dos terrenos Ocidental e Embu e da Klippe Paraíba do Sul (Heilbron et al. 2004). Invariavelmente, todas estas unidades do embasamento, na área de estudo, ocorrem sob a forma corpos alongados, de direção NE-SW, seguindo o trend regional da Faixa Ribeira (Fig. 1). 
De acordo com a última proposta para a litoestratigrafia dos depósitos sedimentares paleogênicos da bacia de Volta Redonda (Fig. 2), apresentada por Sanson et al. (2006), temse, da base para o topo, a seguinte sucessão:

- Formação Ribeirão dos Quatis - associada à fase pré-rifte da evolução da bacia de Volta Redonda. Os depósitos desta unidade estáo dispostos diretamente sobre o embasamento cristalino pré-cambriano, geralmente não ultrapassando mais do que $10 \mathrm{~m}$ de espessura. Sáo constituídos por conglomerados quartzosos médios a grossos, ocorrendo intercalaçôes de arenitos feldspáticos e ainda, de forma subordinada, pelitos. Foram interpretados como sistemas fluviais entrelaçados de alta energia;

- Formação Resende - relacionada à fase principal de sedimentação da bacia de Volta Redonda. Os depósitos desta unidade encontram-se dispostos em inconformidade com o embasamento cristalino pré-cambriano. Sáo caracterizados essencialmente por intercalaçóes de

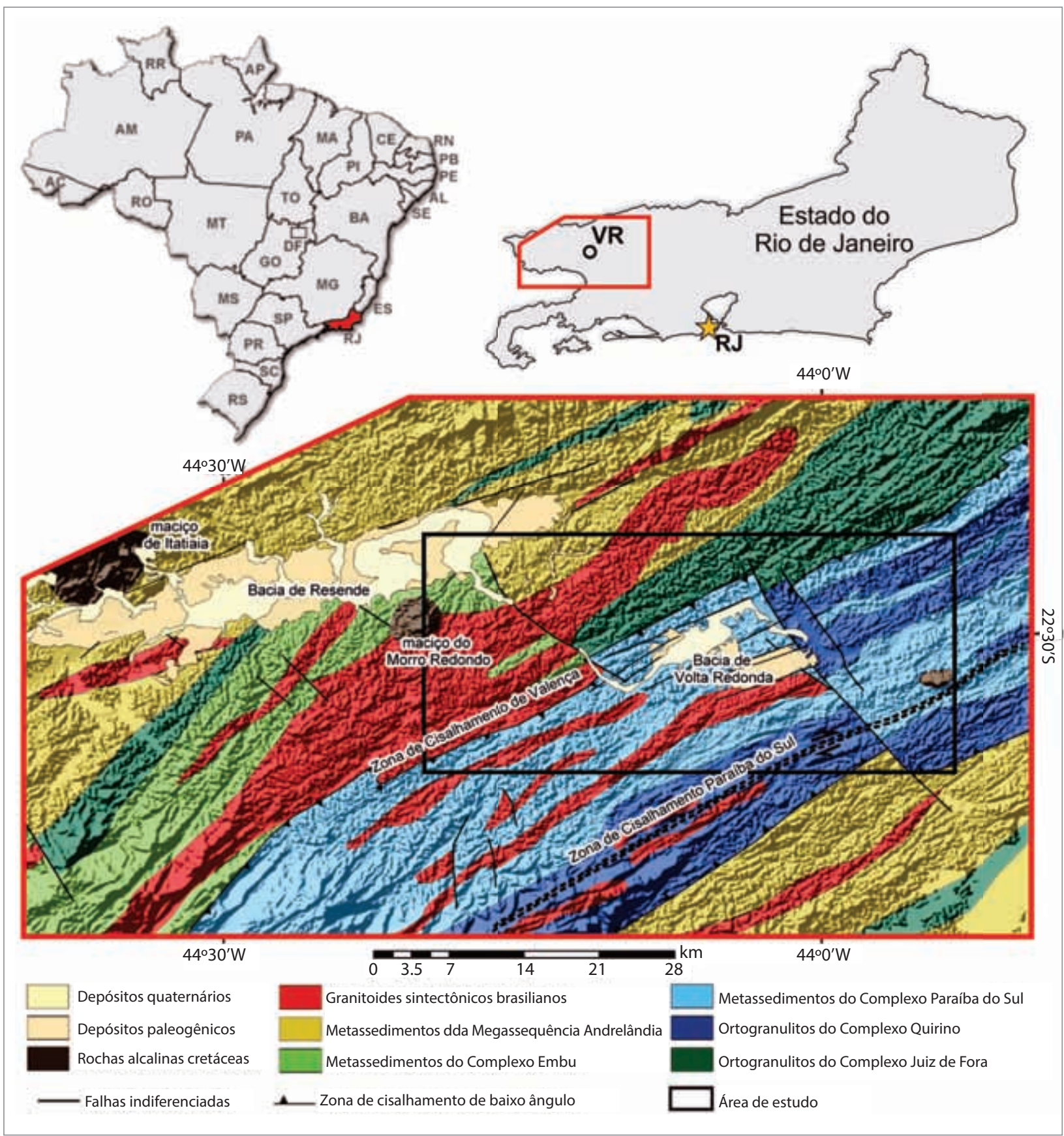

Figura 1. Mapa geológico simplificado do segmento central da Faixa Ribeira na região das bacias de Resende e Volta Redonda, apresentando a localização da área do presente estudo. Mapa geológico original modificado de Heilbron et al. (2004) sobre MDE/SRTM adquirido no site: http://seamless.usgs.gov. 
arenitos feldspáticos estratificados e conglomerados finos, ocorrendo ainda, de forma expressiva, lamitos esverdeados e brechas. Estes depósitos são associados a leques aluviais e sistemas fluviais axiais de padrão entrelaçado;

- Basanito Casa de Pedra - derrames de rocha vulcânica ultramáfica alcalina posicionado entre as formaçóes Resende e Pinheiral. A rocha apresenta textura afanítica, contendo microfenocristais, vesículas e amígdalas, e feições que sugerem, pelo menos, dois derrames superpostos. Ramos et al. $(2005,2008)$ registraram no bairro Vila Rica (Volta Redonda) uma espessura total dos derrames em torno de $11 \mathrm{~m}$, e obtiveram, através do método Ar-Ar, idade de 49,5 \pm 0,4 Ma para estas rochas, posicionando-as no Eoceno inicial (Lutetiano);

- Formação Pinheiral - depósitos que colmatam o preenchimento sedimentar paleogênico da bacia de Volta Redonda, encontrando-se em discordância sobre o embasamento, a Formação Resende e, localmente, sobre o Basanito Casa de Pedra. São caracterizados por conglomerados e arenitos estratificados, relacionados a canais fluviais entrelaçados, com a presença de espessos intervalos pelíticos relacionados a períodos de afogamento do sistema fluvial.
Sanson (2006) identificou quatro fases tectônicas rúpteis na evolução da bacia (Fig. 2), correlacionadas àquelas propostas por Riccomini et al. (2004) para o RCSB. A primeira fase (E1), correspondendo a uma distensão NW-SE e idade paleogênica, é responsável pela abertura e principal preenchimento sedimentar e vulcanismo na bacia. As demais fases (TS, TD e E2) têm caráter deformador. A fase TS, relacionada a uma transcorrência sinistral E-W, é representada por estruturas afetando somente depósitos paleogênicos, não atingindo coberturas neogênicas e quaternárias, conferindo-lhe uma idade entre o Oligoceno final e o Mioceno. A fase TD é relacionada a uma transcorrência dextral E-W, admitindo-se uma idade pleistocênica, por apresentar estruturas afetando depósitos paleogênicos e neogênicos, e não tendo sido constatada deformação por estruturas desta fase nos depósitos holocênicos. A fase E2, vinculada a uma distensão NW-SE, é representada por estruturas afetando todo o registro Cenozoico até o Holoceno.

\section{MATERIAIS E MÉTODOS}

Primeiramente, foram gerados e analisados modelos digitais de elevação (MDEs) produzidos pelo Projeto RJS-25

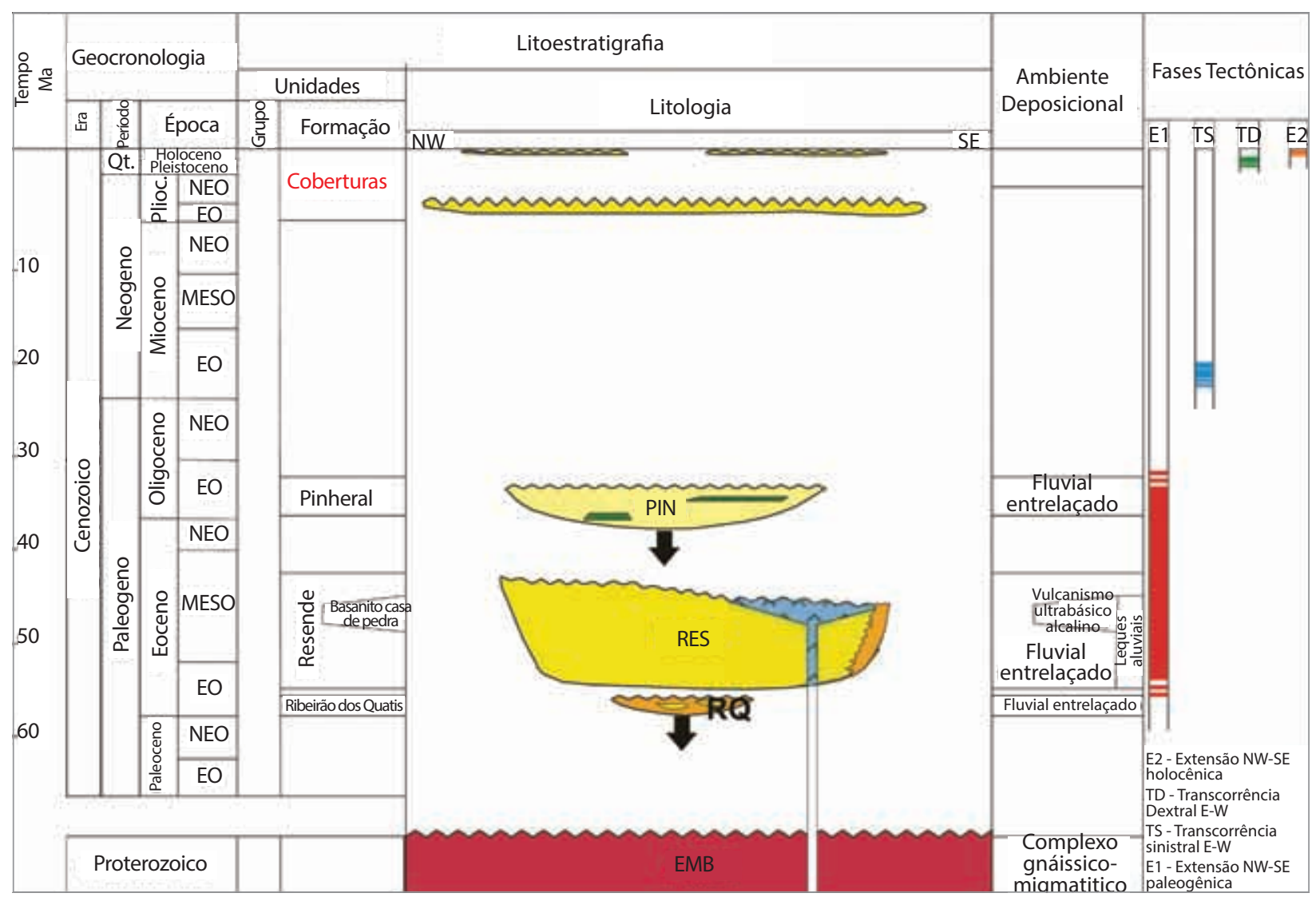

Figura 2. Coluna litoestratigráfica e fases tectônicas da bacia de Volta Redonda (Sanson et al. 2006). 
(IBGE 2006), na escala 1:25.000, abrangendo uma área correspondente à articulação dos seguintes quadrantes das folhas 1:50.000 do IBGE: Bananal (NE), Volta Redonda (NE e NW), Piraí (NW), Resende (SE), Nossa Senhora do Amparo (SE e SW) e Barra do Piraí (SW).

Com o uso da função Hillshade do ArcMap $^{\text {TM }} 9.2$ (ESRI 1999), foram geradas imagens a partir de dois azimutes de iluminação $\left(45^{\circ}\right.$ e $\left.315^{\circ}\right)$, de modo a ressaltar diferentes orientaçóes de estruturas do terreno, mantendo-se o ângulo zenital de $45^{\circ}$.

A distinção entre morfoestruturas vinculadas ao embasamento e unidades de mapeamento cenozoicas também foram auxiliadas pela análise de mapas hipsométricos e ortofotos do Projeto RJ25 (IBGE 2006).

A etapa de campo consistiu em levantamentos sistemáticos, com o objetivo de detalhar os limites das ocorrências de depósitos paleogênicos já conhecidas e de cartografar novas ocorrências. Sempre que possível, foram elaborados perfis litofaciológicos e painéis arquiteturais dos afloramentos investigados, tendo como finalidade a correlaçáo entre associaçóes de fácies e o reconhecimento das unidades litoestratigráficas da bacia de Volta Redonda. Foi realizado, ainda, o levantamento de estruturas rúpteis (falhas) controladoras e deformadoras do registro sedimentar cenozoico.

\section{RESULTADOS}

Foram caracterizados, na região da bacia de Volta Redonda, três depocentros principais com registro sedimentar paleogênico e dois depocentros com registro aflorante essencialmente quaternário, além de diversas ocorrências descontínuas de idade paleogênica (Fig. 3). Os limites entre estes setores são definidos, principalmente, por complexos sistemas de falhas vinculadas ao estágio Rifte e amplamente reativadas por estruturas neotectônicas. Alguns detalhes destes aspectos (arranjo estrutural geral e desenvolvimento de zonas de transferência e acomodação) serão discutidos ao final deste capítulo.

O mais relevante dos depocentros paleogênicos corresponde ao graben de Casa de Pedra (Melo et al. 1983) que, além de conter o registro aluvial mais completo da bacia, também inclui em seu preenchimento as únicas manifestaçôes vulcânicas eocênicas reconhecidas no segmento central do RCSB. No presente estudo, são propostos novos limites para este setor. Ao leste e contíguo ao graben de Casa de Pedra, encontra-se o graben de Dorândia, ora proposto, com preenchimento essencialmente aluvial. Na porçáo oeste da área de estudo, encontra-se a menor feição com registro aluvial paleogênico contínuo, aqui definida como graben de Colônia Santo Antônio.

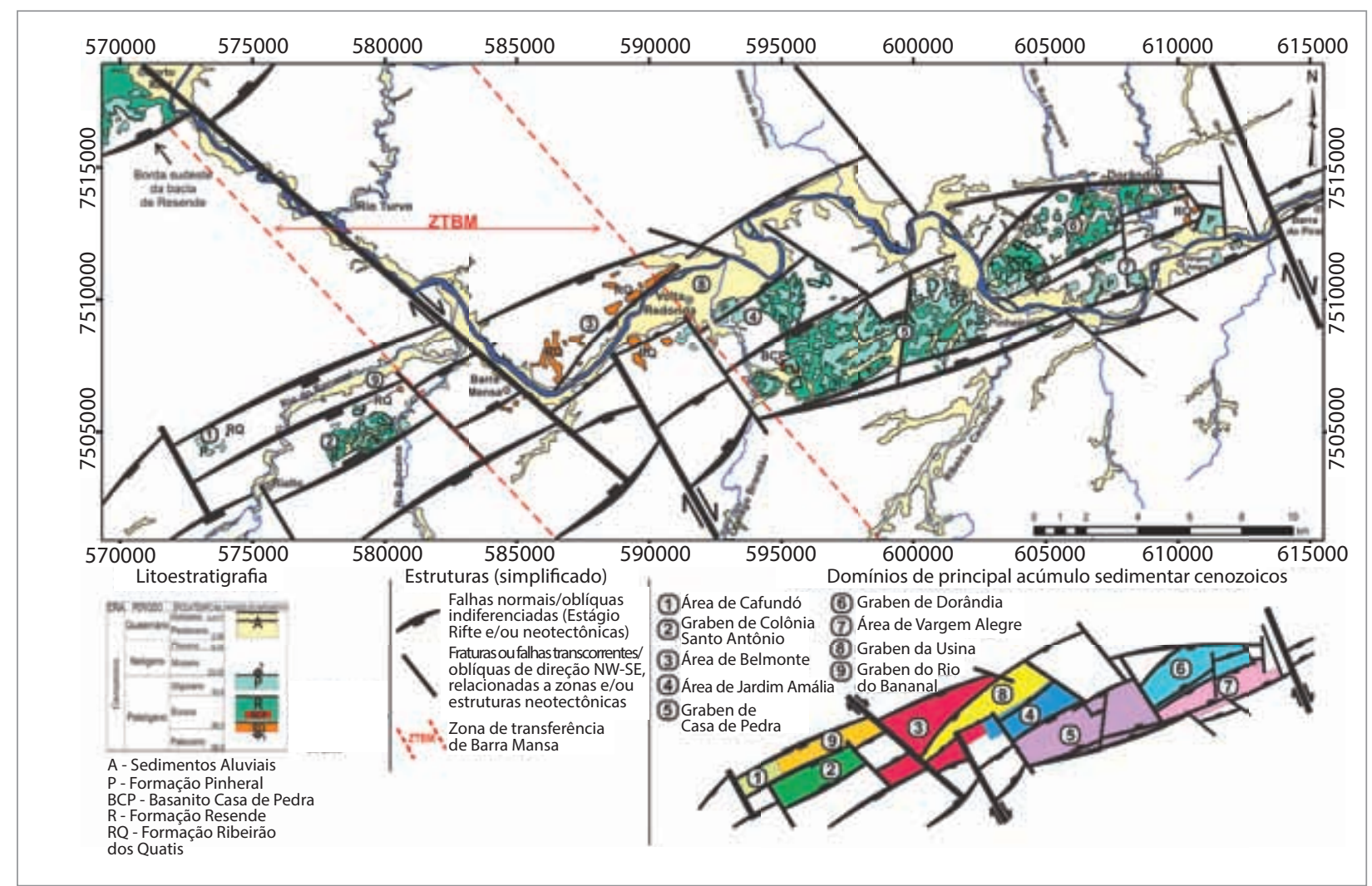

Figura 3. Mapa geológico do cenozoico da região da bacia de Volta Redonda exibindo os diversos domínios estabelecidos no presente estudo, além dos principais sistemas de falhas responsáveis pela geração e deformação deste setor do Rifte Continental do Sudeste do Brasil. 
De oeste para leste, as principais áreas com registros paleogênicos descontínuos foram definidas como: área de Cafundó (descrita inicialmente por Carmo 1996), situada no extremo oeste da área de estudo; área de Belmonte, situada na borda norte/noroeste da área; área do Jardim Amália, situada na porção central da área de estudo, ao norte/noroeste do graben de Casa de Pedra; área de Vargem Alegre, situada ao sul/sudeste do graben de Dorândia, contíguo a este.

Os grabens com registro sedimentar aflorante exclusivamente quaternário são aqui definidos como: graben da Usina, com maior expressão em área, situado na porção centro-norte da área de estudo, acomodando a ampla calha sedimentar atual do rio Paraíba do Sul, onde se localiza o principal núcleo urbano e industrial da cidade de Volta Redonda; e graben do Rio do Bananal, situado no baixo curso do rio homônimo até a confluência com o rio Paraíba do Sul, na porção oeste da área de estudo e ao norte do graben de Colônia Santo Antônio.

\section{Aspectos morfoestratigráficos e morfoestruturais da área de mapeamento}

Os registros sedimentares paleogênicos mais relevantes da região da bacia de Volta Redonda apresentam-se distribuídos segundo a direção NE-SW e compartimentados transversalmente (Fig. 4). As principais formas de relevo do registro paleogênico caracterizam-se por colinas com topos e encostas relativamente suaves em relação às do embasamento, apresentando moderado grau de dissecação e dispostas em arranjos lineares em diferentes direçóes, sendo mais marcantes as de orientação NE-SW e NW-SE. Normalmente, ocorrem em cotas topográficas entre 420 e $500 \mathrm{~m}$ de altitude. Em diversos locais, mas principalmente na regiâo do graben de Casa de Pedra, estes depósitos são observados sustentando relevo de colinas de cristas fortemente alinhadas e com maior grau de dissecação. Nestes casos, tais feiçóes estão frequentemente relacionadas ao desenvolvimento de falhas.

O embasamento se distingue dos depósitos paleogênicos por apresentar formas de relevo com rugosidade mais elevada, apresentando encostas com alta declividade, vales estreitos e cristas fortemente alinhadas segundo as direçóes NE-SW e NW-SE. Entretanto, em diversas situaçôes, tais critérios geomorfológicos não foram suficientes para a distinção entre embasamento e registro sedimentar paleogênico, sendo distinguidas somente através dos levantamentos de campo. Ainda assim, algumas dúvidas permanecem devido

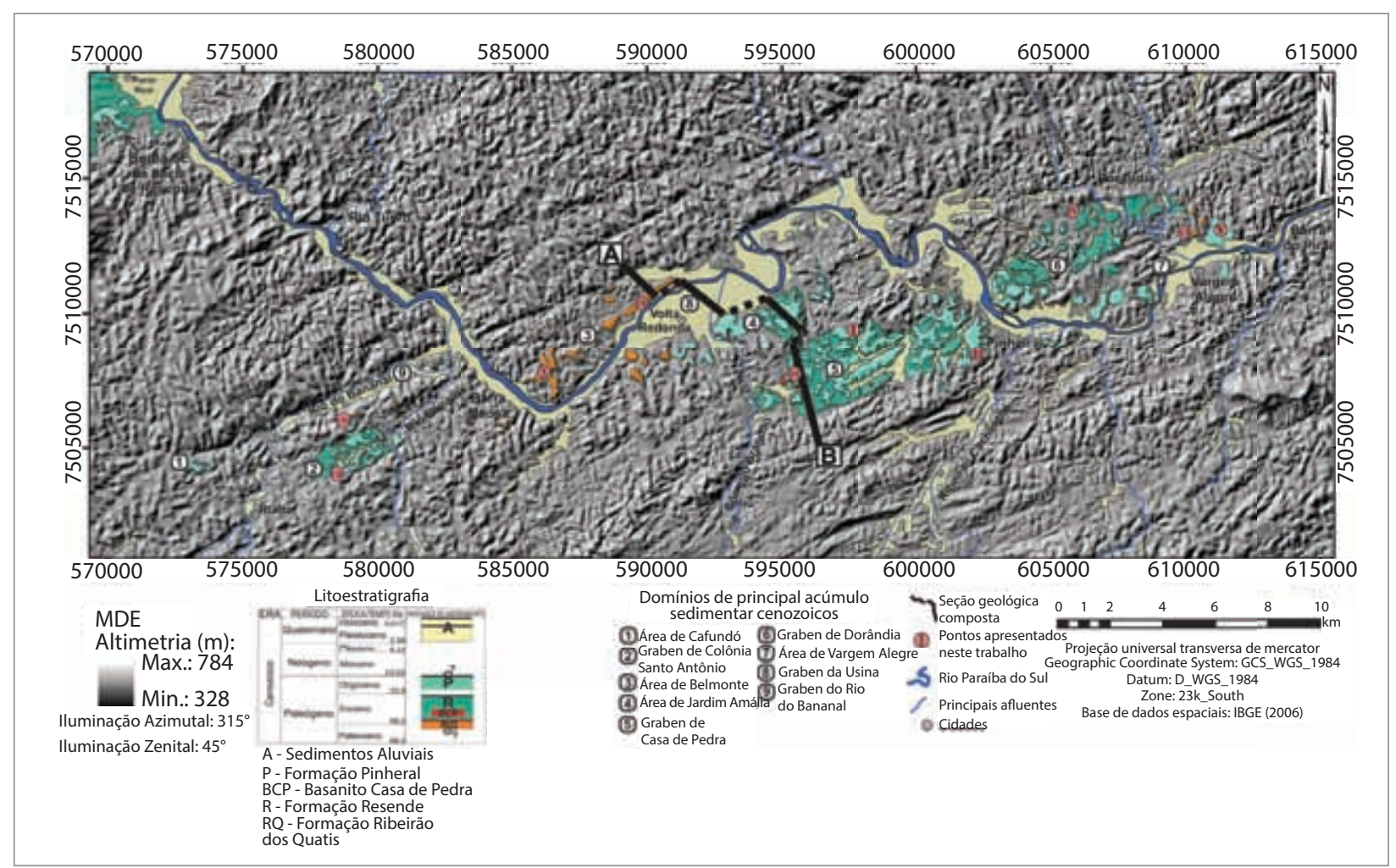

Figura 4. Mapa geológico das unidades cenozoicas sobre modelos digitais de elevação, de modo a se enfatizar as principais morfoestruturas controladoras do registro paleogênico e quaternário. Estão indicadas as áreas ora definidas e a localização dos pontos com painéis litofaciológicos, além do traçado das seções geológicas apresentadas nas Discussões deste trabalho. 
à escassez de afloramentos, principalmente na região do graben de Dorândia.

Os depósitos aluviais quaternários são caracterizados por formas de relevo planas, relacionados a terraços e planícies de inundação, ocorrendo, quase sempre, próximos às cotas topográficas do nível de base local.

\section{Grabens paleogênicos}

\section{Graben de Casa de Pedra e área de Jardim Amália}

O graben de Casa de Pedra constitui o principal depocentro da regiāo da bacia de Volta Redonda, apresentando dimensôes máximas em torno de $9 \mathrm{~km}$ na direção NE-SW e $3 \mathrm{~km}$ na direção NW-SE. Seu preenchimento compreende os depósitos aluviais das formaçôes Resende e Pinheiral, além do registro de rochas vulcânicas ultrabásicas alcalinas (Basanito Casa de Pedra).

Neste depocentro, a Formação Resende é a que apresenta maior distribuição em área, perfazendo um preenchimento contínuo. Seu contato discordante com o embasamento é frequentemente observado nas bordas do graben, não sendo verificado em seu interior. A espessura máxima aflorante identificada para esta unidade alcança cerca de $30 \mathrm{~m}$, sendo o local de maior espessura constatada da unidade em toda região da bacia. Os depósitos da Formação Resende no graben de Casa de Pedra são caracterizados, essencialmente, por arenitos lamosos e lamitos arenosos esverdeados (Fig. 5), conglomerados finos a médios e lentes de argilitos esverdeados, relacionados a sistemas fluviais entrelaçados, apresentando frequentes direçóes de paleocorrente para sudeste. Fácies fanglomeráticas proximais são observadas junto à borda sul, diagnosticando esta como a borda principal (Fig. 6). Ao longo da borda oposta, não são verificados depósitos desta natureza, sugerindo uma provável assimetria nas taxas de subsidência deste setor.

Os derrames basaníticos afloram na porção oeste do graben de Casa de Pedra, sobre os depósitos da Formação Resende e sobrepostos por depósitos da Formação Pinheiral (Fig. 7). O avançado grau de alteração dos afloramentos disponíveis deixa dúvidas acerca de seu exato posicionamento estratigráfico. Desta forma, permanece a questão se tal vulcanismo ocorreu durante a deposição da Formação Resende (conforme Riccomini 1989; Riccomini et al. 2004) ou após (conforme Sanson 2006; Sanson et al. 2006). Neste estudo, assume-se o posicionamento estratigráfico proposto por Riccomini (1989) e Riccomini et al. (2004), sendo sugerida a possibilidade de a incisão fluvial da Formação Pinheiral ter promovido a erosão de possíveis depósitos da Formação Resende que estariam recobrindo os derrames basaníticos.
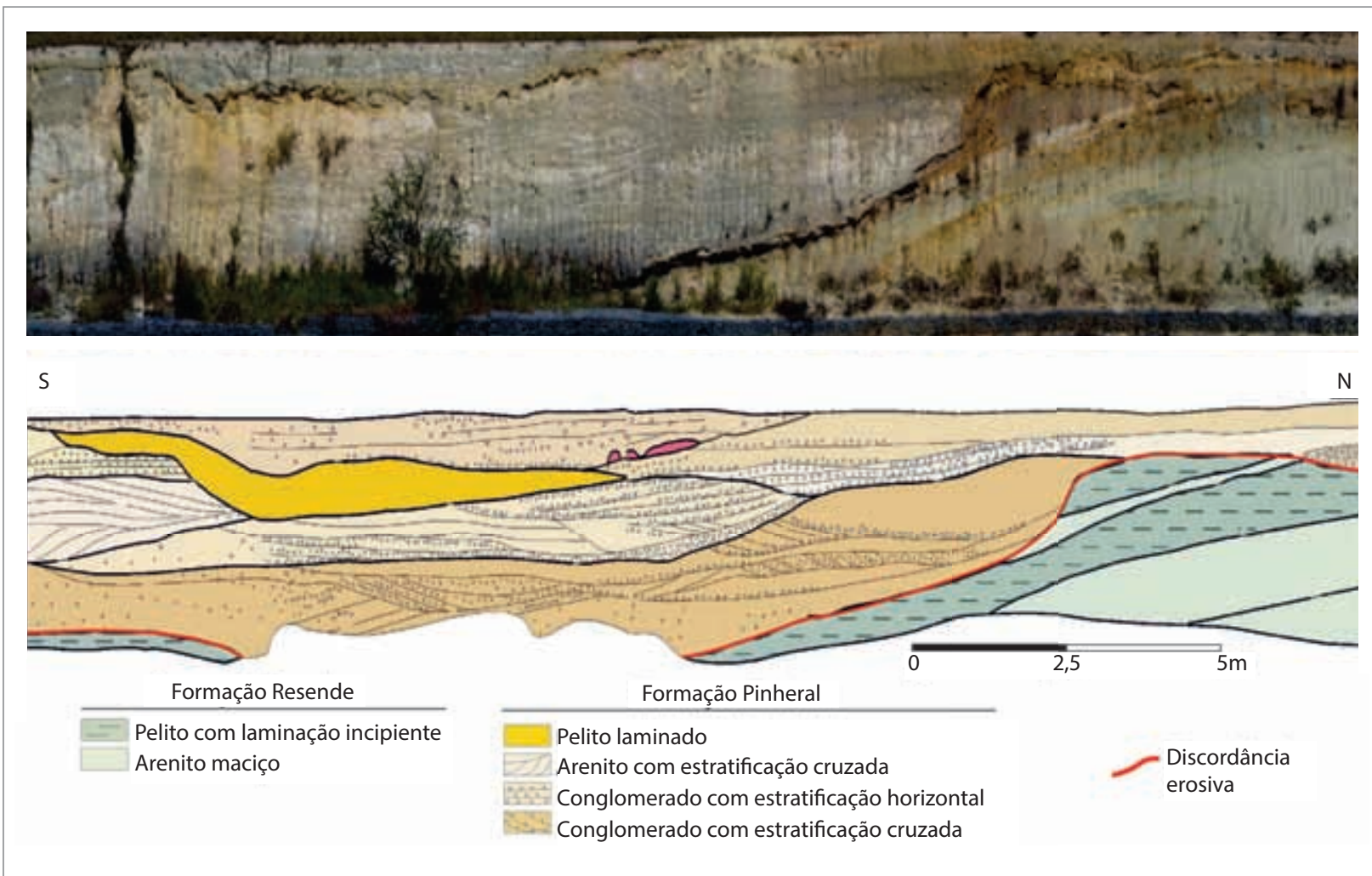

Figura 5. Ponto I (UTM: 0597610/7509309 - Fuso 23k, Datum WGS-1984). Seção faciológica representativa das formações Resende e Pinheiral na borda norte do graben de Casa de Pedra, Rodovia do Contorno (BR-393). 
Os depósitos da Formação Pinheiral são verificados no graben de Casa de Pedra dispostos quase sempre em discordância sobre a Formação Resende (Fig. 5) e, mais raramente, em alguns locais de suas bordas, sobre o embasamento. Neste e nos demais domínios, a Formação Pinheiral não apresenta variaçóes faciológicas significativas, sendo caracterizada por espessos pacotes de arenitos feldspáticos estratificados e ortoconglomerados quartzosos, com níveis de intraclastos argilosos, relacionados ao preenchimento de canais fluviais, e espessos pacotes pelíticos, depositados em planícies de inundação e canais abandonados.

Ocorrências ao norte do graben de Casa de Pedra, aqui reunidas como área de Jardim Amália, são constituídas por depósitos fluviais relacionados às formaçóes Resende e Pinheiral. Nesta área, os limites dos depósitos são marcados por recuos erosivos e por falhas geradas ou reativadas por eventos neotectônicos.

\section{Graben de Dorândia e área de Vargem Alegre}

Na porção leste da área de estudo, encontram-se os setores definidos como graben de Dorândia e área de Vargem
Alegre, contíguos ao graben de Casa de Pedra, sendo separados deste apenas pelo rio Paraíba do Sul, sob forte controle estrutural de direção NW-SE.

O graben de Dorândia apresenta dimensóes máximas em torno de $8,2 \mathrm{~km}$ na direção NE-SW e $2,5 \mathrm{~km}$ na direção NW-SE. O preenchimento sedimentar paleogênico é dado pelas associaçóes de fácies das formaçóes Resende e Pinheiral, além de ocorrências restritas de depósitos relacionados à Formação Ribeirão dos Quatis sobre altos estruturais em seu extremo leste.

Neste graben, a Formação Resende é frequentemente observada em contato direto com o embasamento e, quando assim registradas, exibe espessuras inferiores a $20 \mathrm{~m}$. Fácies lamíticas maciças são as mais recorrentes neste setor. Arenitos lamíticos e conglomerados ocorrem de forma subordinada, como elementos arquiteturais de canais estreitos (Fig. 8). Tal associação sugere paleoambientes caracterizados por planícies lamosas distais com canais fluviais entrelaçados esparsos. Fácies fanglomeráticas proximais são constatadas nas proximidades da borda norte/nordeste desta área,

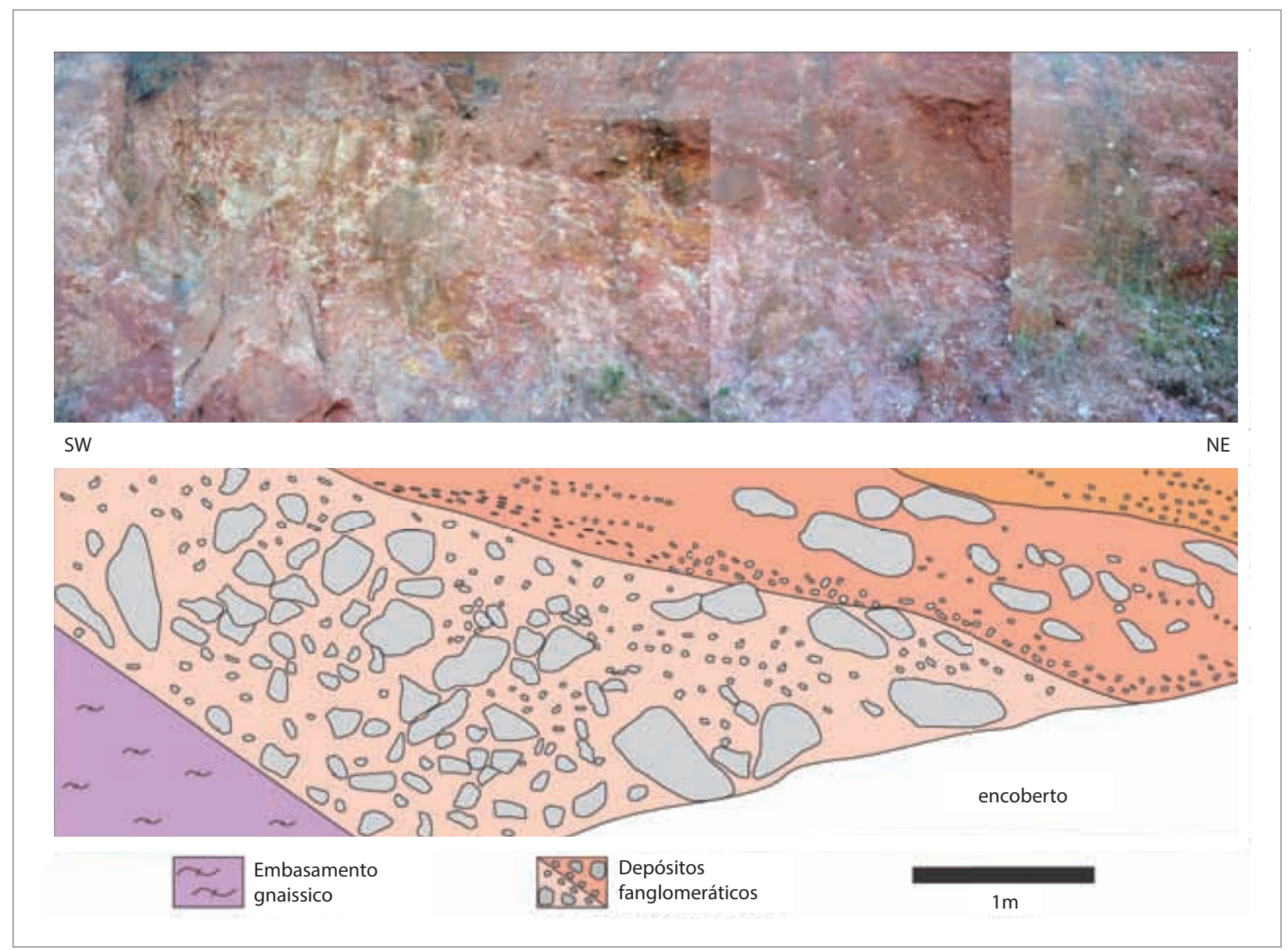

Figura 6. Ponto II (UTM: 602754/7508630 - Fuso 23k, Datum WGS-1984). Depósitos fanglomeráticos da Formação Resende, dispostos diretamente sobre o embasamento da bacia. Borda sul do graben de Casa de Pedra, município de Pinheiral. 
sugerindo uma significativa atividade tectônica no tempo de sua deposição.

A Formação Pinheiral também apresenta espessura máxima em torno de $20 \mathrm{~m}$, sendo encontrada quase sempre em discordância sobre a Formação Resende, com exceção das áreas de borda, onde é verificada em onlap ou em contato por falha com o embasamento. Em termos de associaçóes de fácies, a Formação Pinheiral não apresenta variaçôes em relação às características descritas no graben de Casa de Pedra.

Os limites do graben de Dorândia, ao norte e ao sul, são definidos por sistemas de direção NE-SW. Admite-se que este graben possua perfil assimétrico, com sua borda de falha principal situada a norte, assim definida em decorrência da presença de litofácies fanglomeráticas e devido às expressóes morfoestruturais/topográficas. Nos limites ao leste e ao oeste, são observadas estruturas subordinadas, aproximadamente ortogonais às principais, predominando direçóes NW-SE e NNW-SSE.
A área de Vargem Alegre, que se encontra separada do graben de Dorândia por um alto de provável origem neotectônica, consiste em uma depressão com dimensóes máximas em torno de $6 \mathrm{~km}$ na direção NE-SW e $3 \mathrm{~km}$ na direção NW-SE, com registro sedimentar paleogênico relativamente descontínuo. Abriga, ainda, uma ampla calha de sedimentação aluvial quaternária, relacionada à dinâmica do rio Paraíba do Sul, que a atravessa em toda sua extensão.

O preenchimento sedimentar paleogênico da área de Vargem Alegre é caracterizado essencialmente por depósitos da Formação Pinheiral (Fig. 9), com espessura máxima aflorante em torno de $30 \mathrm{~m}$. As formações Ribeirão dos Quatis e Resende têm ocorrências bastante restritas, sendo que a primeira apresenta boas exposições de depósitos conglomeráticos e areníticos com frequentes estruturas de liquefação (Fig. 10).

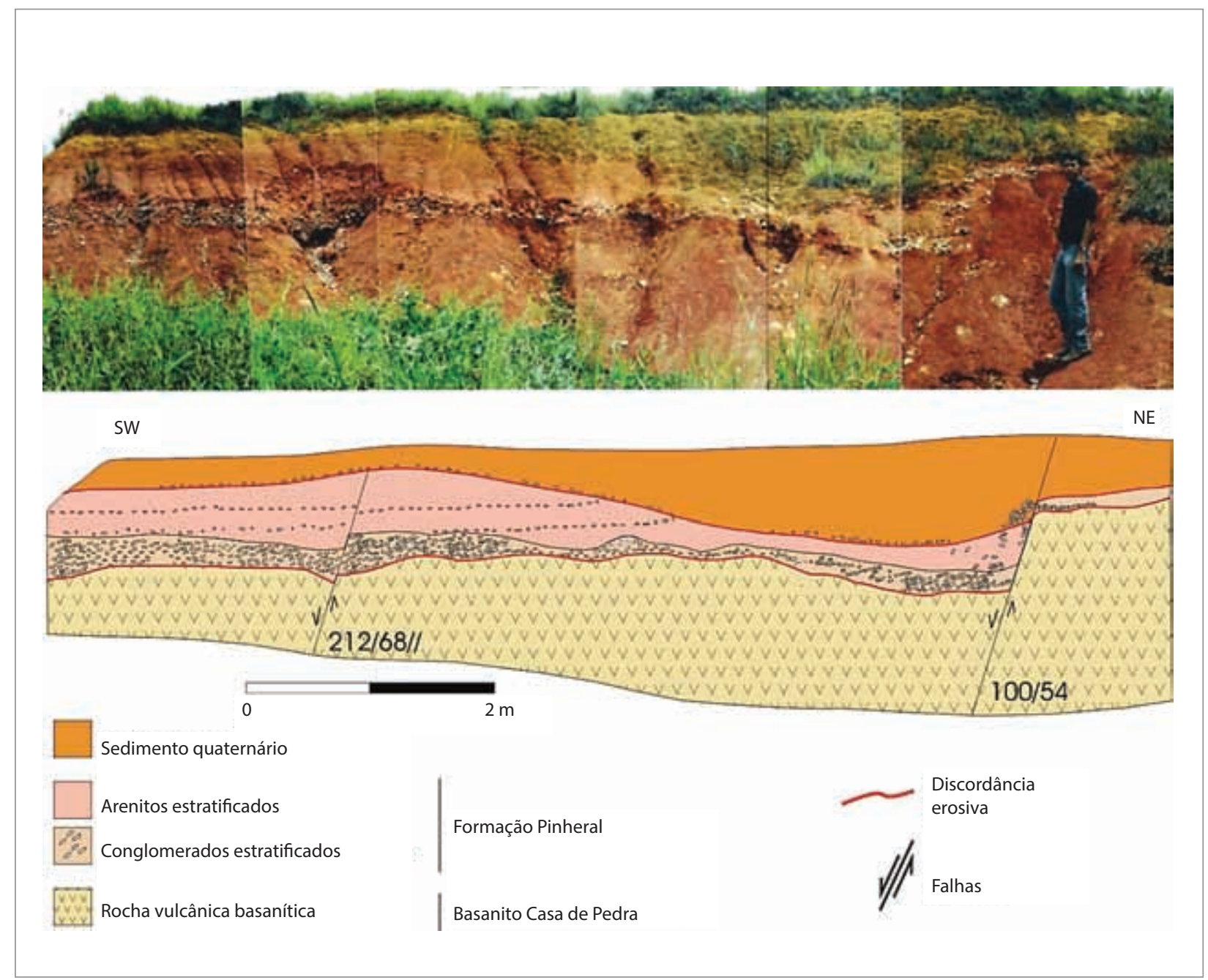

Figura 7. Ponto III (UTM: 0595843/7506870 - Fuso 23k, Datum WGS-1984). Fotomosaico e seção geológica ilustrando depósitos relacionados à Formação Pinheiral em discordância erosiva sobre derrames de rocha ultrabásica alcalina, localizado no final da Rua 42, bairro Vila Rica, no município de Volta Redonda. Notar que todo o conjunto encontra-se intensamente intemperizado. 
O limite sul da área de Vargem Alegre é definido por uma pronunciada borda estrutural, que em seu prolongamento para oeste alinha-se com a borda sul do graben de Casa de Pedra. Nesta área, não foi identificado nenhum registro fanglomerático que pudesse estabelecer de forma efetiva uma borda de falha principal.

\section{Graben de Colônia Santo Antônio e área do Cafundó}

No extremo oeste da área de estudo ocorre um depocentro contínuo, aqui definido como graben de Colônia Santo Antônio, bem como a área do Cafundó, caracterizada por ocorrências descontínuas de depósitos paleogênicos.

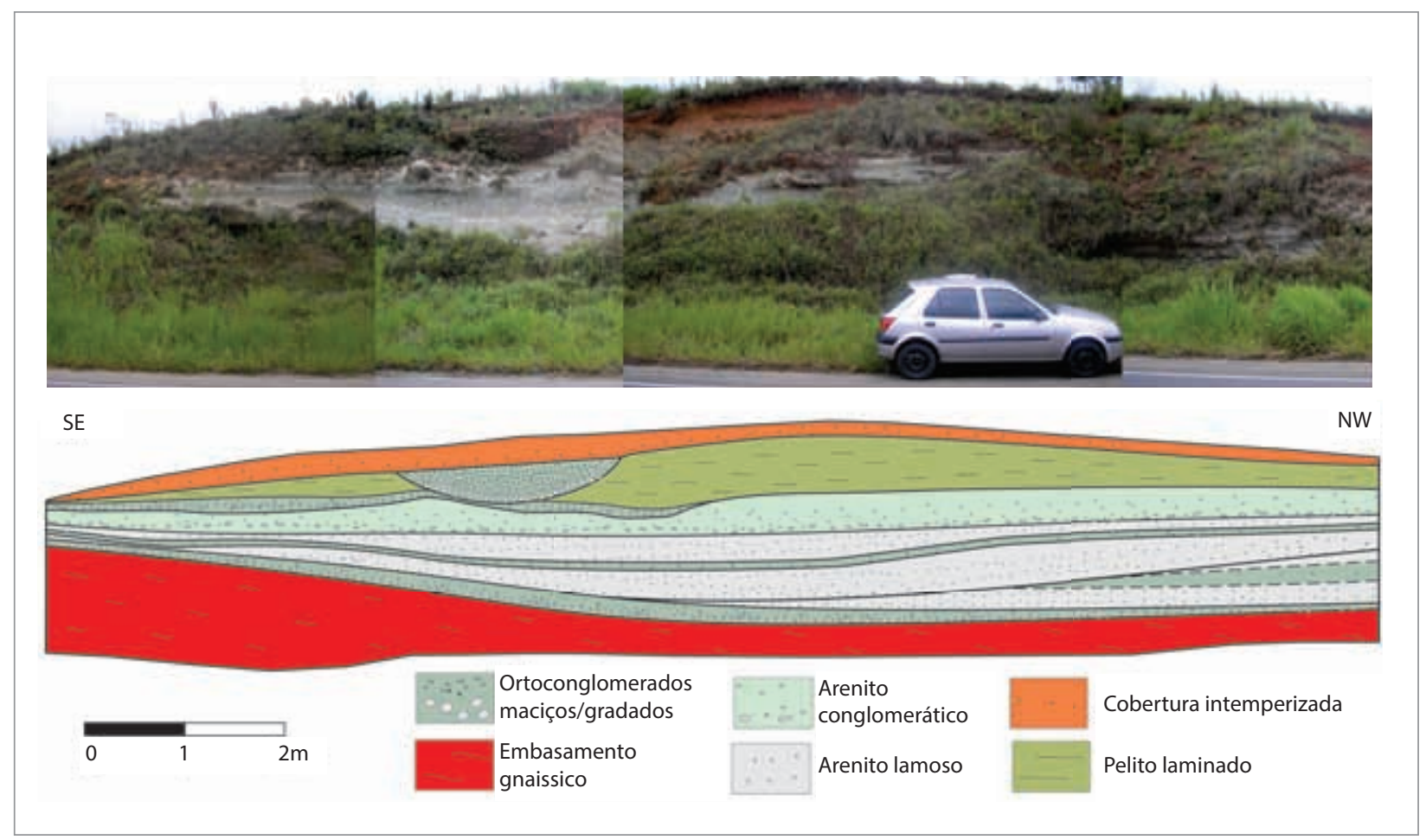

Figura 8. Ponto IV (UTM: 0606073/7513332 - Fuso 23k, Datum WGS-1984). Seção faciológica ilustrando depósitos fluviais da Formação Resende, dispostos diretamente sobre o embasamento. Afloramento situado próximo à borda norte do graben de Dorândia, Rodovia Lúcio Meira (BR-393).

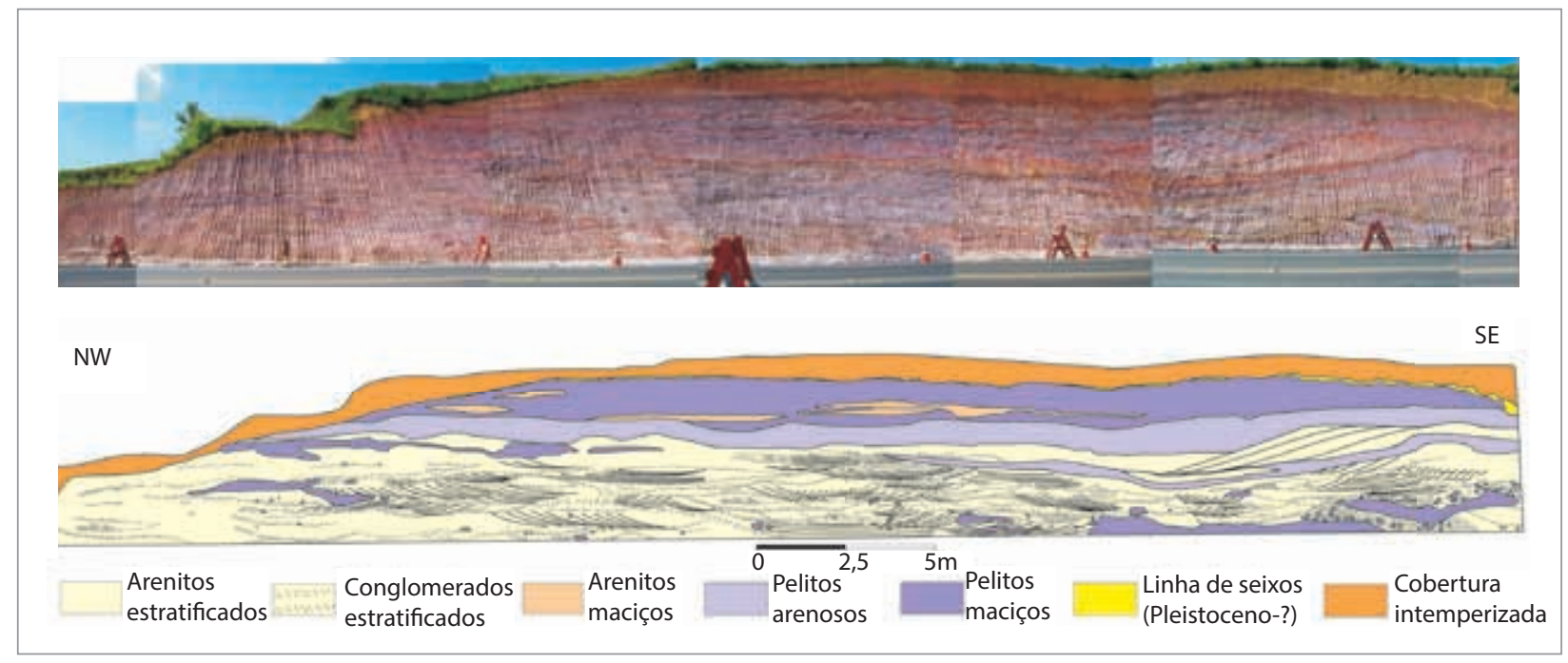

Figura 9. Ponto V (UTM: 0611100/7513217 - Fuso 23k, Datum WGS-1984). Seção ilustrando depósitos fluviais da Formação Pinheiral no extremo leste do área de Vargem Alegre. Afloramento em corte de estrada, Rodovia Lúcio Meira (BR-393), Barra do Piraí. 
O graben de Colônia Santo Antônio apresenta dimensões máximas em torno de 3,0 km na direção NE-SW e 1,4 km na direção NW-SE, sendo seu preenchimento correlacionável às formaçóes Resende e Pinheiral. Depósitos dessas duas unidades, e também da Formação Ribeirão dos Quatis, foram registrados sobre o alto topográfico/estrutural que define a borda norte deste graben. Neste setor, a Formação Resende apresenta-se em contato discordante com o embasamento e é constituída por fácies essencialmente pelíticas e arcóseos lamosos, sem o registro de fácies fanglomeráticas. A Formação Pinheiral caracteriza-se por fácies arcoseanas, conglomeráticas e pelíticas, similarmente ao que se observam nos demais domínios da bacia.

O graben apresenta bordas de falha bem definidas ao norte e ao sul, sendo a primeira de natureza aparentemente deformacional, a julgar pela ocorrência descontínua de depósitos paleogênicos no topo deste. A borda sul é possivelmente a principal, uma vez que se apresenta com maior
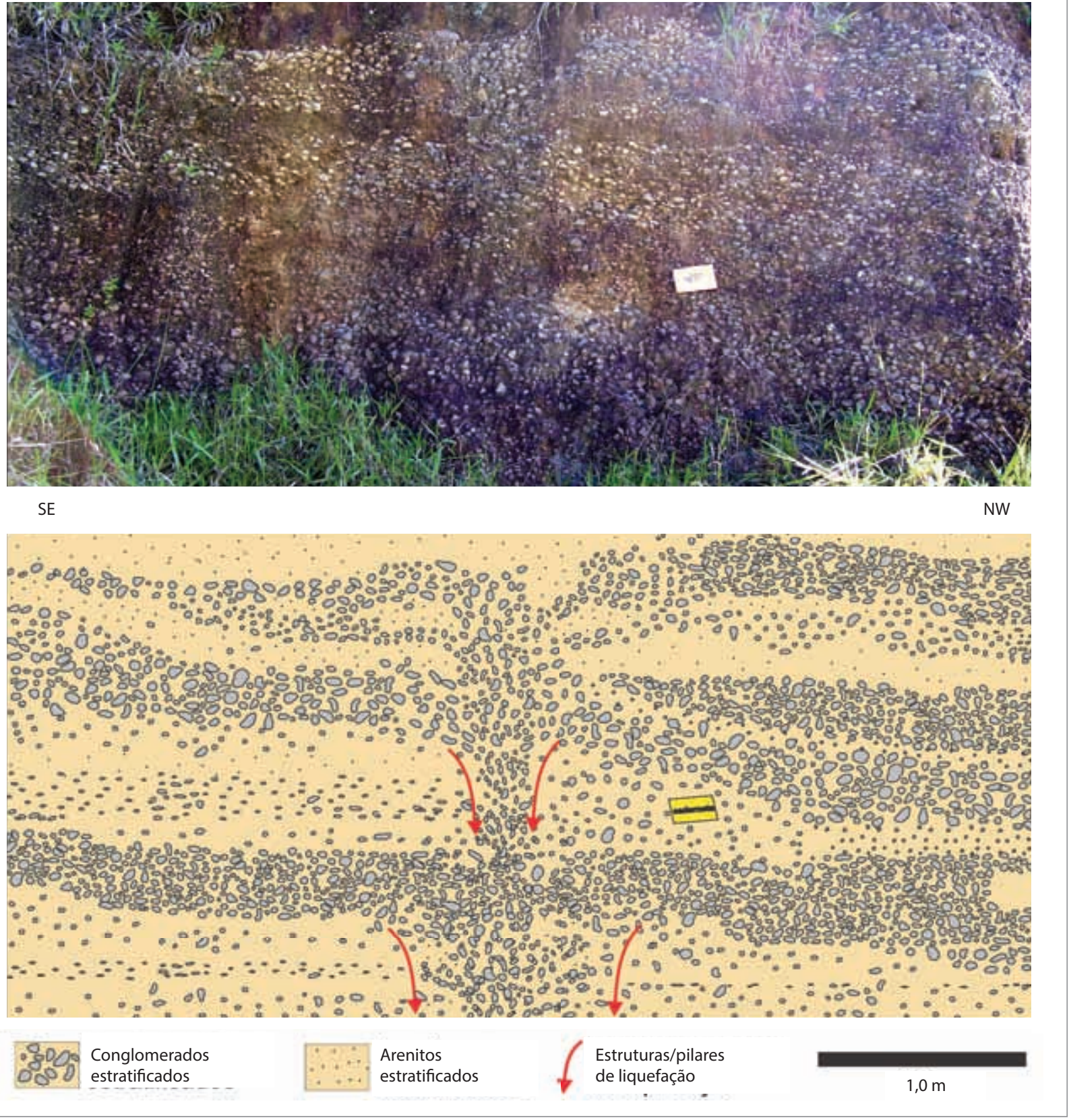

Figura 10. Ponto VI (UTM: 0610345/7513042 - Fuso 23k, Datum WGS-1984). Intecalação de ortoconglomerados e arenitos relacionados a Formação Ribeirão dos Quatis, apresentando notáveis estruturas de liquefação. 
declividade e presença de facetas triangulares e knickpoints (Fig. 11). Os limites ao leste e ao oeste são marcados por estruturas subordinadas de direção NW-SE.

$\mathrm{Na}$ ocorrência situada sobre a borda norte deste graben foram identificados, de forma inédita, conglomerados médios a grossos correlacionáveis à Formação Ribeirão dos Quatis sotopostos a depósitos lamíticos esverdeados relacionados à Formação Resende (Fig. 12), e também a depósitos areníticos e conglomeráticos da Formação Pinheiral. Desta forma, fica estabelecida, pela primeira vez, a relação

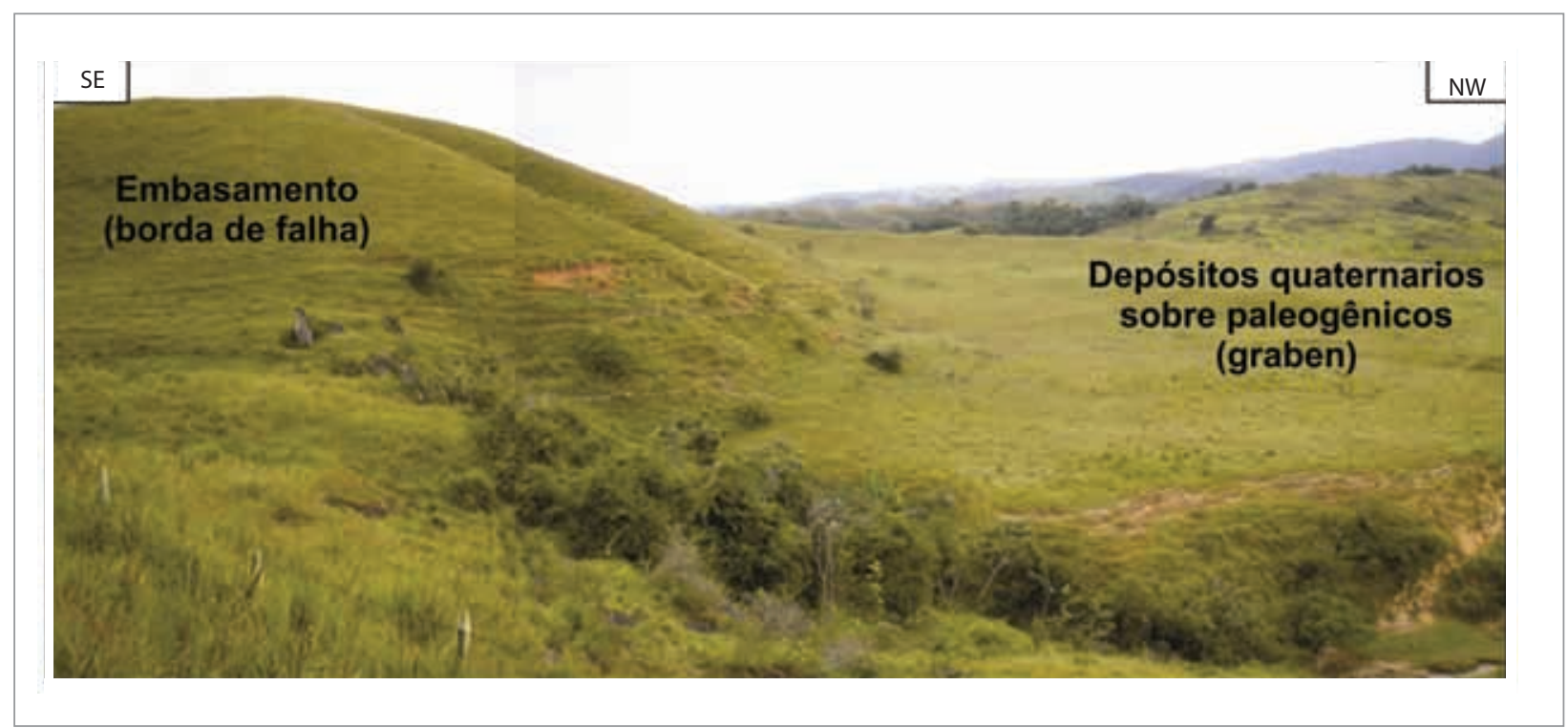

Figura 11. Ponto VII (UTM: 0578177/7503855 - Fuso 23k, Datum WGS-1984). Aspecto morfoestrutural da borda de falha ao sul/sudeste do graben de Colônia Santo Antônio.

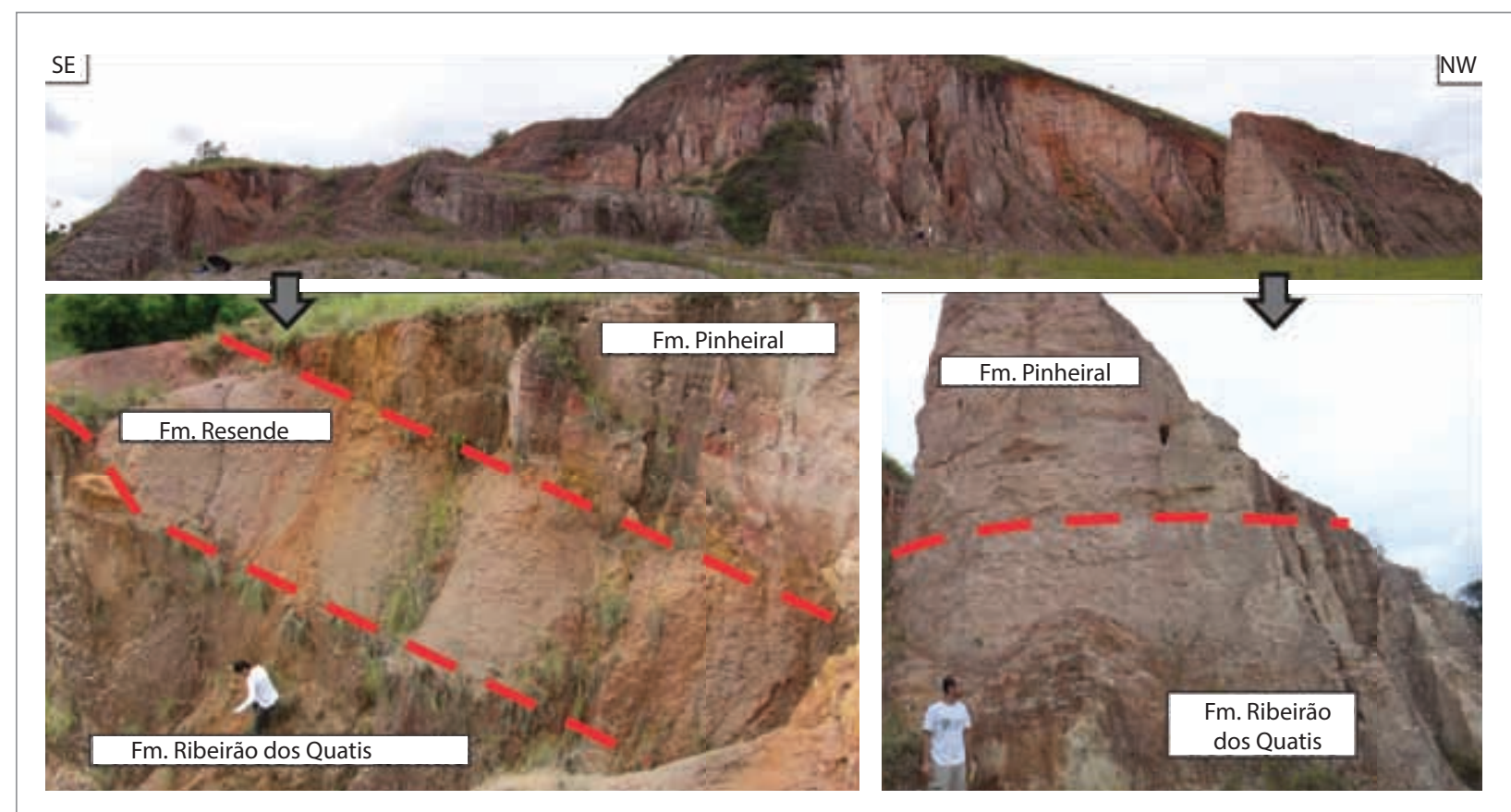

Figura 12. Ponto VIII (UTM: 0579216/7505966 - Fuso 23k, Datum WGS-1984). Fotomosaico e fotos de detalhe ilustrando os provaveis contatos entre unidades estratigráficas. À esquerda, sucessões de camadas conglomeráticas relacionados à Fm. Ribeirão dos Quatis sotopostas a lamitos da Fm. Resende e, ao topo, arenitos e conglomerados da Fm. Pinheiral. Notar que todo este conjunto encontra-se rotacionado tectonicamente para SW. À direita, associação de fácies constituída por arenitos e conglomerados relacionados à Fm. Pinheiral em discordância (linha vermelha) à associação de fácies essencialmente conglomerática relacionada à Fm. Ribeirão dos Quatis. 
de contato entre as três unidades paleogênicas da região da bacia de Volta Redonda.

$\mathrm{Na}$ área do Cafundó ocorrem depósitos paleogênicos correlacionáveis a Formação Ribeirão dos Quatis, apresentando-se isolados, com espessura máxima em torno de $15 \mathrm{~m}$, e observados sempre sobre o embasamento. Consiste em sucessóes de litofácies ortoconglomeráticas polimíticas, intercaladas com arenitos feldspáticos.

\section{Área de Belmonte}

A área de Belmonte, situada na porção noroeste da regiẫo estudada, consiste no principal sítio deposicional da Formação Ribeirão dos Quatis. Nesta área, os depósitos desta unidade ocorrem de forma descontínua sobre colinas de embasamento de direção NE-SW, quase sempre restrito aos altos estruturais ao norte e ao sul da calha do rio Paraíba do Sul. Apresentam pouca espessura, normalmente menor que $10 \mathrm{~m}$, sendo seus limites laterais frequentemente condicionados por falhas.

As associaçóes de fácies desta unidade não apresentam diferenças significativas nas suas diversas ocorrências, caracterizando-se por intercalaçóes de camadas tabulares de conglomerados médios a grossos, polimíticos; arenitos feldspáticos estratificados; além de delgadas lentes pelíticas subordinadas. Neste e em outros estudos (Ramos 1997, 2003, Ramos et al. 2006, Sanson 2006, Sanson et al. 2006), os depósitos desta unidade são relacionados a um registro de sistemas fluviais entrelaçados. Outro aspecto diagnóstico desta unidade é a presença de estruturas de liquefaçáo (Fig. 13) desenvolvidas em resposta a eventos sísmicos enquanto encontravam-se saturadas em água (Bezerra et al. 2005). Com alguma frequência, também se observa a ocorrência de conglomerados basais portadores de matacóes arredondados de quartzo com até $40 \mathrm{~cm}$ de diâmetro (Fig. 14).

Depósitos fluviais relacionados às formaçôes Resende e Pinheiral, apresentando dimensôes não mapeáveis, são observados nesta área, em sua porção ao norte do rio Paraíba do Sul.

\section{Grabens quaternários}

Na região da bacia de Volta Redonda, é notável a presença de pelo menos dois depocentros de sedimentação controlada por eventos neotectônicos. $\mathrm{O}$ mais expressivo, definido

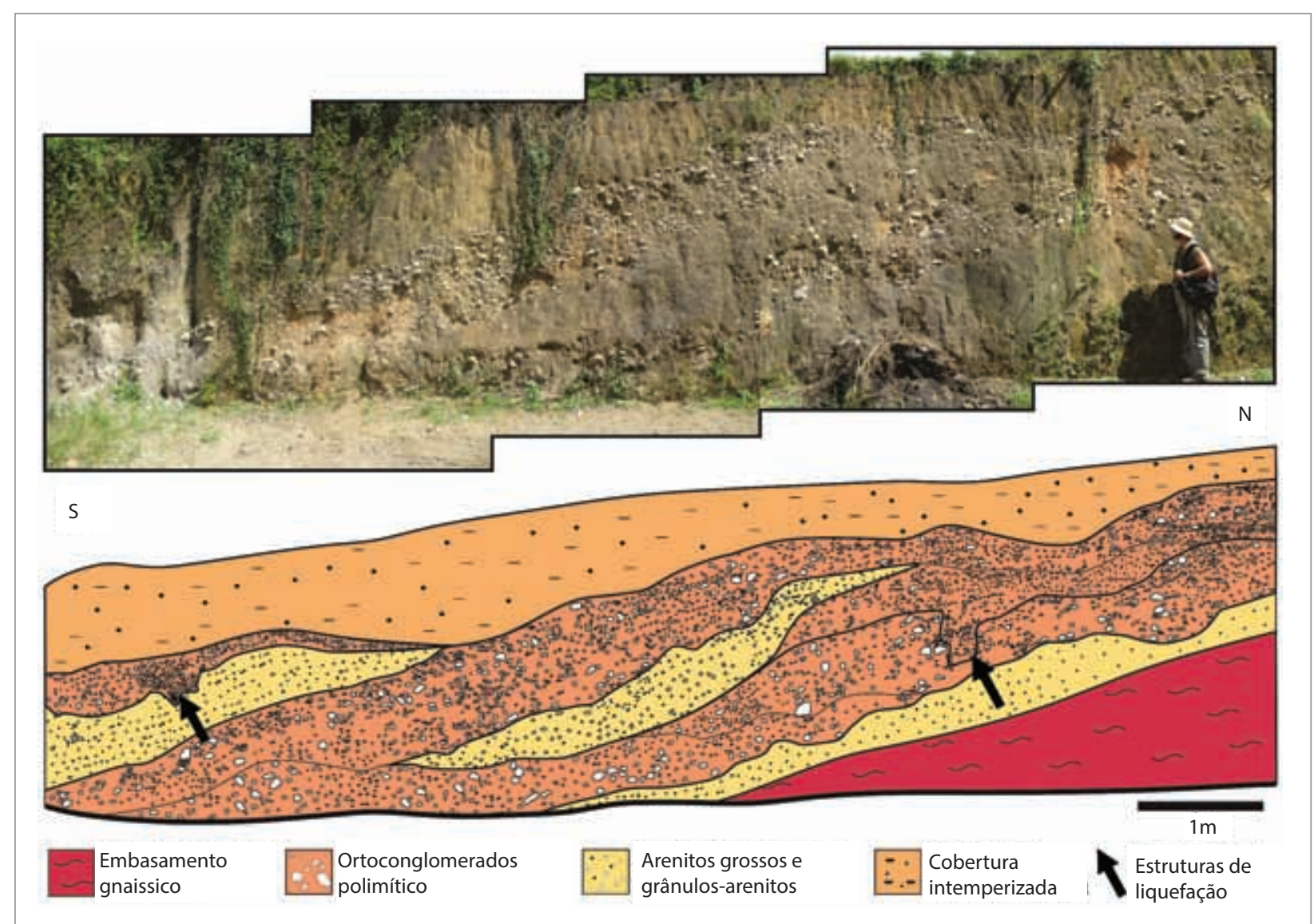

Figura 13. Ponto IX (UTM: 0590044/7510422 - Fuso 23k, Datum WGS-1984). Seção ilustrando associação de depósitos areníticos e conglomeráticos da Formação Ribeirão dos Quatis, com destaque para a presença de estruturas de liquefação e possível basculamento tectônico do conjunto. Área de Belmonte, município de Volta Redonda. 
como graben da Usina, está situado na porção central da área de estudo (Figs. 3 e 4 - mapas), e acomoda o núcleo urbano e industrial do município de Volta Redonda. Com menor expressão em área, foi definido o graben do Rio do Bananal, situado na porção oeste da área de estudo. Verifica-se, ainda, a presença de outras áreas com importante sedimentação quaternária ao longo da calha do rio Paraíba do Sul, entre Pinheiral e Barra do Piraí.

O graben da Usina apresenta dimensóes máximas em torno de $11 \mathrm{~km}$ na direção NE e $3 \mathrm{~km}$ na direção NW. Seus limites ao norte e ao sul são definidos por falhas normais, consideradas assim com base em dados estruturais obtidos em campo e, também, pelo caráter morfoestrutural de suas bordas. A proximidade do Rio Paraíba do Sul, quase sempre junto à borda norte deste gráben, sugere que esta apresente maior atividade recente em relação à borda oposta. Os limites ao leste e ao oeste do graben da Usina são definidos por estruturas subordinadas de direção predominante NW-SE.

Quando aflorante, o registro sedimentar é composto por litofácies arenosas, lamosas e cascalhosas, relacionandose à dinâmica fluvial recente. Do ponto de vista morfoestratigráfico, são observados diversos níveis de sedimentação quaternária, desde barras de acreção lateral e demais elementos arquiteturais relacionados à dinâmica atual do rio Paraíba do Sul, até níveis de terraços mais elevados e antigos. Foram observados, em escavaçôes para obras da rede de água e esgoto nos limites sul/sudeste do graben $\mathrm{da}$ Usina, a uma profundidade de aproximadamente $4 \mathrm{~m}$, depósitos com características semelhantes aos registros fluviais da Formação Resende. Desta forma, admite-se que este graben tenha a sua origem, ao menos em parte, vinculada aos estágios de abertura da bacia. Esta hipótese também é corroborada pela ocorrência de depósitos das formaçóes Resende e Pinheiral encerrados abruptamente por falhas normais ao longo da borda sul deste graben, na área do Jardim Amália.

O graben do Rio do Bananal comporta o baixo curso do rio homônimo, até o encontro deste com o rio Paraíba do Sul. Apresenta uma alta relação comprimento/largura, tendo dimensôes máximas em torno de $7,5 \mathrm{~km}$ na direção NE por 1,0 km na direção NW. A borda norte deste graben consiste em uma proeminente feição topográfica, com alta declividade e desnível por vezes superior a $200 \mathrm{~m}$, interpretada como a borda principal. Adicionalmente, o rio do Bananal flui, de forma persistente, junto à borda norte, sendo outra evidência de subsidência recente, com assimetria para NW.

O preenchimento sedimentar aflorante no graben do Rio do Bananal consiste em uma estreita faixa de depósitos fluviais atuais, além de terraços fluviais com prováveis idades pleistocênicas a holocênicas.

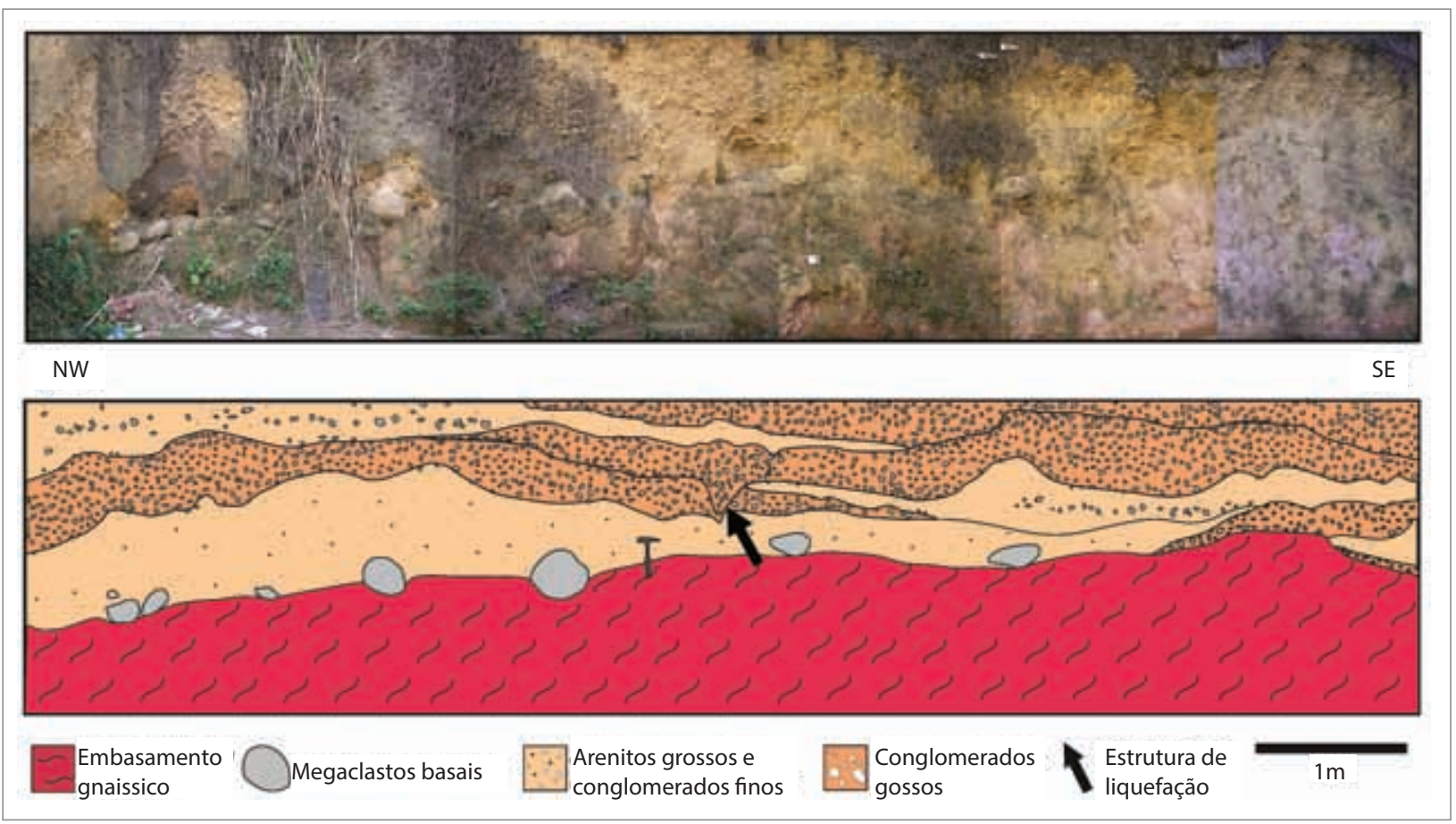

Figura 14. Ponto X (UTM: 0586120/7507640 - Fuso 23k, Datum WGS-1984). Seção ilustrando associação de depósitos areníticos e conglomeráticos da Formação Ribeirão dos Quatis, com destaque para a presença de estruturas de liquefação e de megaclastos de quartzo em sua porção basal, em contato com o embasamento. Área de Belmonte, município de Barra Mansa. 


\section{Síntese sobre a distribuição do registro cenozoico}

Em síntese, todo o registro cenozoico ocorre, predominantemente, ao longo de trend estrutural de direçáo NE-SW, estando segmentados ortogonalmente.

Os depósitos da unidade mais antiga, Formação Ribeirão dos Quatis, encontram-se sempre dispostos sobre o embasamento, ao longo de altos estruturais externos aos principais depocentros paleogênicos.

A Formação Resende tem sua ocorrência essencialmente restrita aos grabens paleogênicos ora definidos, com exceção para a área de Jardim Amália, que se configura em alto estrutural entre os grabens de Casa de Pedra (ao sul) e da Usina (ao norte). A esta unidade vincula-se o principal estágio tectônico da bacia, a julgar por sua relação com o basanito Casa de Pedra e presença de depósitos de leques aluviais relacionados a bordas de falhas ativas, constatados na borda sul do graben de Casa de Pedra e borda nordeste do graben de Dorândia.

De forma similar, a Formação Pinheiral também tem sua ocorrência predominantemente sobre os depocentros paleogênicos. Entretanto, apresenta-se, em alguns locais, de forma mais isolada, a exemplo das áreas de Jardim Amália e Vargem Alegre.

\section{Coluna litoestratigráfica}

Apresenta-se aqui um novo desenho da coluna litoestratigráfica para a região da bacia de Volta Redonda (Fig. 15). A sucessão e idades máximas e mínimas das unidades não foram alteradas em relação à coluna proposta por Sanson (2006). Entretanto, foram efetuadas correçôes em relação às discordâncias erosivas e seu controle sobre as amplitudes temporais de cada unidade, principalmente sobre os registros da Formação Resende e derrames vulcânicos do Basanito Casa de Pedra. Com base na distribuição espacial, aspectos faciológicos e natureza de suas discordâncias, as unidades paleogênicas também foram individualizadas em termos de tectonossequências, por corresponderem a diferentes estágios tectônicos de abertura dos depocentros paleogênicos. Desta forma, a Formação Ribeirão dos Quatis foi denominada como Tectonossequência I, correspondendo à fase Pré-rifte; Formação Resende como Tectonossequência II, correspondendo a Fase Rifte I (inicial e principal); e Formação Pinheiral como Tectonossequência III, correspondendo a Fase

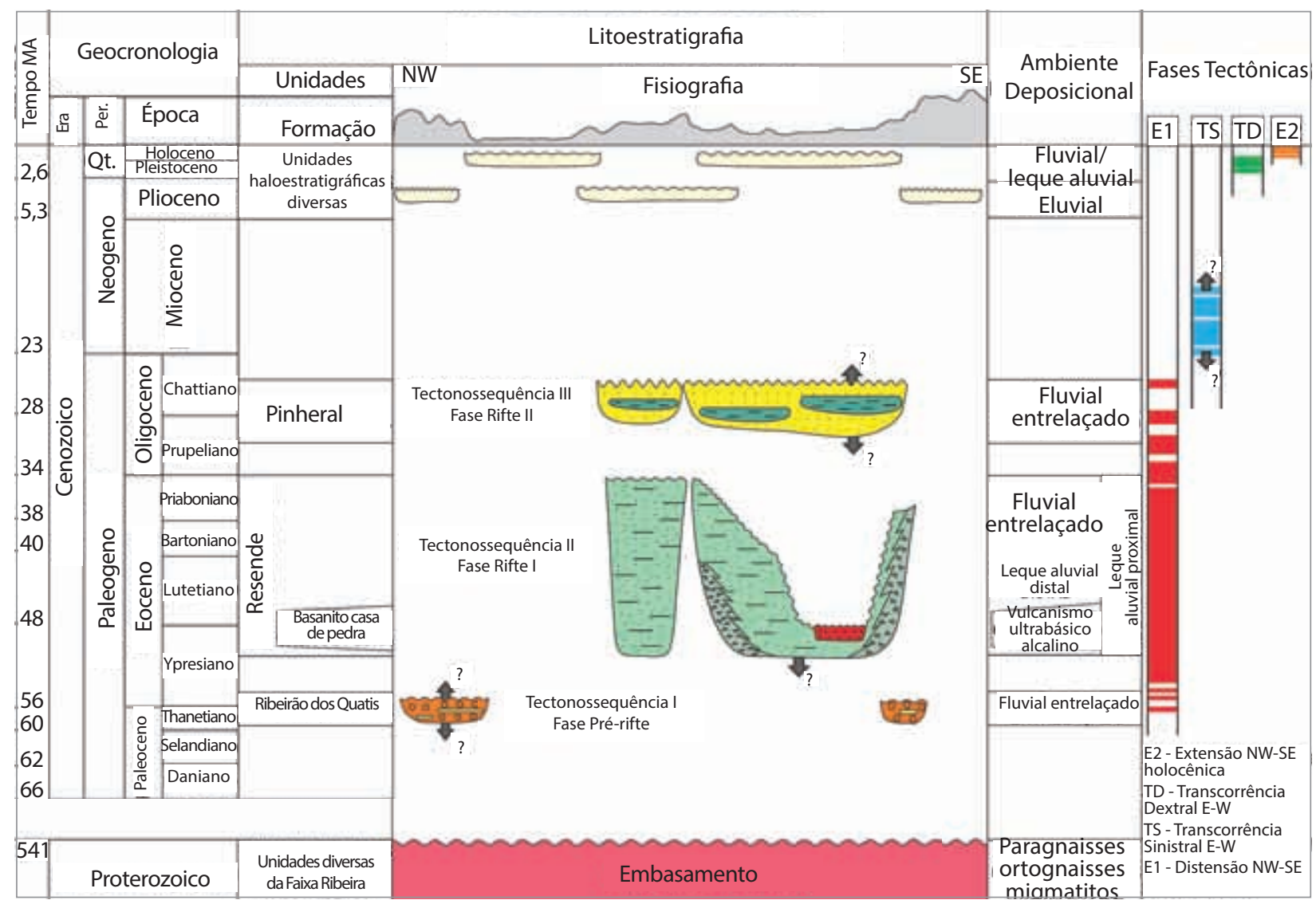

Figura 15. Coluna litoestratigráfica da região da bacia de Volta Redonda, modificada a partir da proposta de Sanson (2006). 
Rifte II (final). Também foi atualizada a distribuição lateral das unidades cenozoicas, além da inserção de um perfil fisiográfico regional, de modo a confrontar, genericamente, a distribuição do registro sedimentar e vulcânico em relação aos principais elementos geomorfológicos.

\section{Considerações sobre o arranjo estrutural geral da região da bacia de Volta Redonda}

A partir do mapa geológico ora apresentado (Figs. 3 e 4), a região da bacia de Volta Redonda foi subdividida em três setores estruturais principais.

O mais relevante deles é o graben de Casa de Pedra e suas regiôes contíguas, o que inclui o graben da Usina e área de Jardim Amália ao norte/noroeste; e graben de Dorândia e área de Vargem Alegre, ao leste/nordeste. Os atuais limites estruturais entre estes compartimentos estáo, muito provavelmente, relacionados à reativaçáo neotectônica de zonas de transferência e de acomodação (sensu Faulds \& Varga 1998) paleogênicas. A este conjunto de depocentros e ocorrências descontínuas, controlados por tais sistemas de estruturas, atribui-se a bacia de Volta Redonda stricto sensu.

Da mesma forma, o gráben de Colônia Santo Antônio e suas regiôes contíguas (graben do Rio do Bananal e área de Cafundó), também constituiriam, durante o Paleógeno, um sistema de calhas conectadas por zonas de transferência e de acomodação locais, posteriormente deformadas por estruturas neotectônicas.

Ao que tudo indica, a área de Belmonte, com seu registro sedimentar constituído essencialmente por depósitos pré-rifte (Formação Ribeirão dos Quatis), teria se comportado como uma área topograficamente mais elevada quando da abertura desta região do RCSB. Fato este, corroborado, principalmente, pela ausência quase total de depósitos relacionados às formaçôes Resende e Pinheiral.

Além das zonas de transferências locais, também foi reconhecida uma importante zona de transferência regional de caráter dextral, definida neste trabalho como Zona de Transferência de Barra Mansa (ZTBM), responsável, durante o Paleógeno, pelo deslocamento dos esforços distensivos entre as bacias de Resende e Volta Redonda. Na área de estudo a ZTBM teria promovido o desenvolvimento isolado entre o setor da bacia de Volta Redonda (stricto sensu) e o setor do graben de Colônia Santo Antônio. Esta hipótese fundamenta-se, sobretudo, pelo significativo afastamento (aprox. $12 \mathrm{~km}$ ) e o não alinhamento entre os setores da bacia de Volta Redonda e do graben de Colônia Santo Antônio. Neste contexto, a ZTBM teria se desenvolvido em sobreposição a área de Belmonte, o que explicaria a ausência de depocentros neste setor e, em parte, a grande densidade de lineamentos NW-SE e o forte controle estrutural do rio
Paraíba do Sul em seu trecho entre as bacias de Resende e Volta Redonda.

\section{DISCUSSÕES}

\section{Seções geológicas e evolução tectonossedimentar}

As seçôes ora apresentadas (Figs. 16A e 16B) demostram as interpretaçôes, em subsuperfície, dos principais padrões estruturais e de preenchimento sedimentar ao longo do eixo transversal da bacia em seus depocentros cenozoicos mais relevantes, abrangendo, portanto, o graben da Casa de Pedra, área de Jardim Amália, graben da Usina e área de Belmonte.

\section{Estágio Rifte}

Ao admitir-se que as unidades paleogênicas da bacia se depositaram em estágios tectonossedimentares distintos, optou-se por elaborar a seçáo rifte ao tempo de deposição da Formação Pinheiral, de modo a se apresentar um quadro geral para o Paleógeno. O arranjo geométrico da seção rifte (Fig. 16A) apresenta aquele que se interpretou ser o mais coerente com os resultados obtidos. As principais premissas que sustentam o modelo ora proposto são: geometria em hemigraben do setor do graben da Casa de Pedra, com borda de falha principal situada ao sul; diminuiçáo progressiva da espessura sedimentar paleogênica para norte/noroeste no eixo transversal entre o graben de Casa de Pedra e área de Belmonte; ausência de registros fanglomeráticos junto à borda norte/noroeste da bacia; direçáo e mergulho das falhas potencialmente relacionadas aos estágios de abertura da bacia; conjuntos de morfoestruturas (bordas de falhas, altos estruturais e grabens) que, analisadas em conjunto, configuram sistemas grabens/horsts neotectônicos, herdados, em grande parte, dos processos de abertura.

Com base nos resultados apresentados, estabeleceram-se três principais momentos tectonossedimentares: o primeiro corresponde à fase Pré-rifte, provavelmente marcado por fraturamento crustal e desenvolvimento de falhas normais de rejeito incipiente, sendo representado pelo registro fluvial da Formação Ribeirão dos Quatis. A fase Rifte I está relacionada ao principal estágio de abertura, com o desenvolvimento de falhas profundas e geração de hemigrabens com significativas taxas de subsidência, responsável pela deposição dos registros fluviais e de leques aluviais da Formação Resende, além de magmatismo basanítico associado (Basanito Casa de Pedra). A fase Rifte II, responsável pela colmatação paleogênica da bacia, é ainda caracterizada por forte controle na geraçáo de espaço e na distribuição dos depósitos fluviais da Formação Pinheiral. Entretanto, esta última fase paleogênica apresenta prováveis taxas de subsidências inferiores às 
observadas na fase Rifte I, dado o caráter faciológico de seus depósitos fluviais e ausência de registros fanglomeráticos.

De acordo com a presente interpretação, a bacia se apresentaria totalmente preenchida nos setores abrangidos pela seção geológica do Estágio Rifte. Na extremidade sudeste, o principal depocentro, caracterizado pelo hemigraben de Casa de Pedra, teria seus sistemas de falhas principais e sintéticas ao sul; a porçáo central seria caracterizada pelo alto estrutural onde atualmente ocupa a área de Jardim Amália; desta feição até a extremidade norte/noroeste a bacia teria se desenvolvido através de sistemas alternados de falhas sintéticas e antitéticas, com depocentros progressivamente mais rasos em direção à borda norte.

\section{Configuração atual}

A seção geológica esquemática que representa a configuração atual da bacia foi construída a partir da extração de perfil topográfico ao longo do eixo escolhido e extrapolação de feiçóes morfoestruturais e de dados de falhas coletados em campo (Fig. 16B).
Em relação ao registro sedimentar cenozoico, tem-se que as formaçóes Ribeirão dos Quatis e Pinheiral estão representadas com suas espessuras aproximadamente reais, uma vez que os limites basais destas unidades afloram ao longo da seção analisada. Da mesma forma, é possível se fazer uma estimativa da espessura dos depósitos da Formação Resende na área de Jardim Amália. O mesmo não ocorre com os depósitos da Formação Resende no graben de Casa de Pedra e com os aluvióes quaternários no graben da Usina, onde suas porçóes basais são aflorantes apenas nas extremidades deste depocentros, tornandose especulativa a espessura máxima destes registros. Para a Formação Resende no graben de Casa de Pedra, estimou-se uma espessura em torno de $200 \mathrm{~m}$. No que concerne ao Basanito Casa de Pedra, seu posicionamento e a espessura estimada na seção é aproximadamente o que se observa em campo, em torno de 5 a $10 \mathrm{~m}$. A presença de derrames mais antigos, soterrados pelo registro paleogênico, não é descartada.

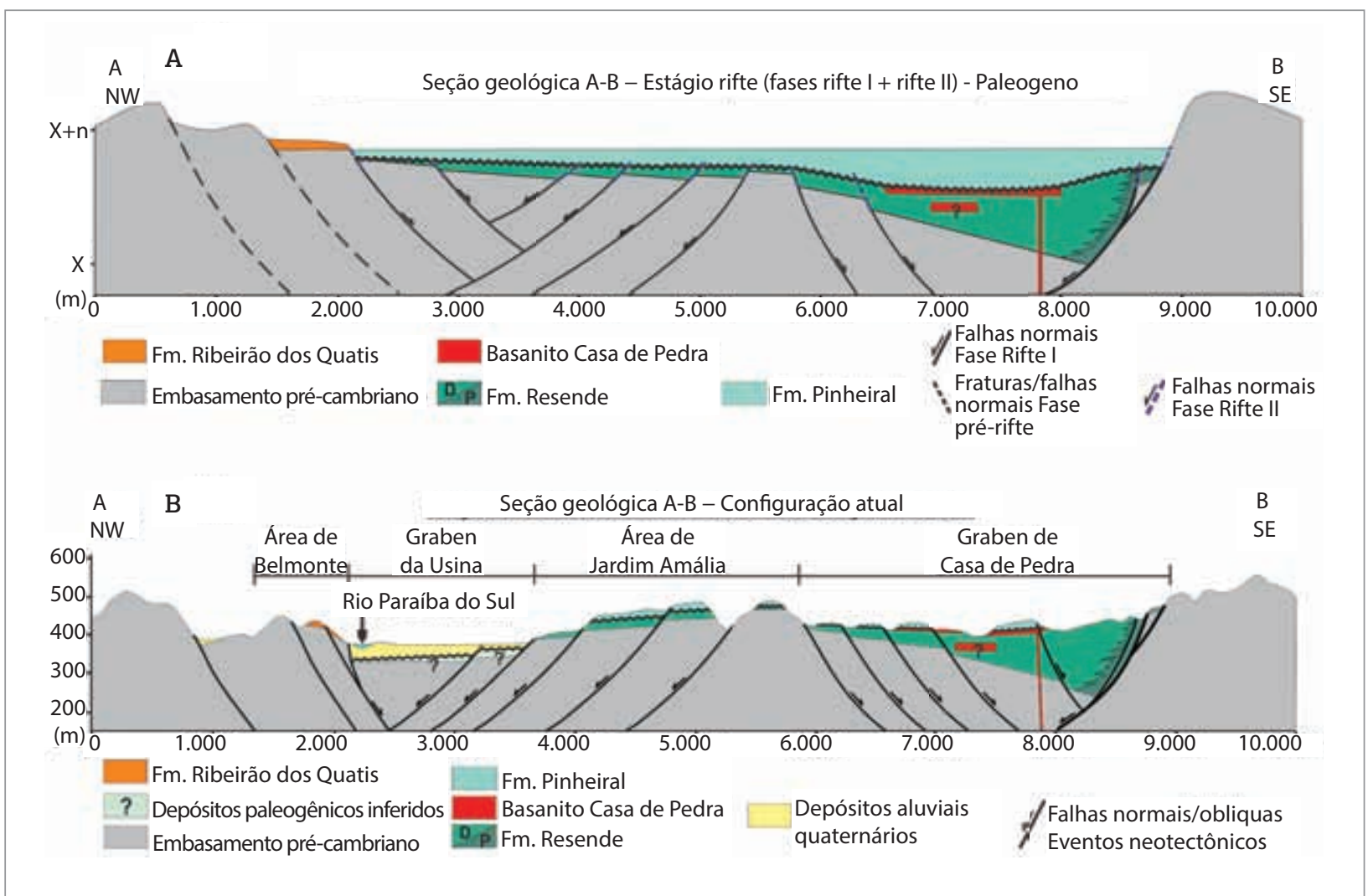

Figura 16. Seções geológicas compostas, abrangendo, conforme demarcado na Fig. 4, o graben de Casa de Pedra, área de Jardim Amália, graben da Usina e área de Belmonte. (A) Seção interpretativa do Estágio Rifte, exibindo uma bacia totalmente preenchida e com geometria geral em hemigraben, com sistemas de falhas sintéticas mergulhando para NW. (B) Seção esquemática representando a configuração atual dos setores abrangidos da bacia, onde se nota uma inversão parcial de depocentros paleogênicos na região definida como graben da Usina, juntamente com uma inversão topográfica relativa da área de Jardim Amália. 
Em síntese, a geometria geral dos depocentros da área de estudo apresenta-se sob a forma de hemigrabens, com o graben de Casa de Pedra basculado para sul (borda de falha principal) e progressiva diminuição da espessura sedimentar para norte; e o graben da Usina, apresentando basculamento para norte, sendo esta característica interpretada como uma inversão por deformação neotectônica, relacionada, principalmente, à atuaçáo do evento E2 (distensão NW-SE). Altos estruturais de direção NE-SW são as principais feiçôes relacionadas à segmentação dos hemigrabens descritos, a exemplo da área de Jardim Amália, que limita os dois depocentros representados na seçấo geológica. Considera-se que tais altos possam ter sua origem já na geração da bacia; entretanto, encontram-se reativados por eventos neotectônicos, evidenciado pela presença de falhas afetando o embasamento e o registro paleogênico e, frequentemente, o registro quaternário.

\section{CONCLUSÕES}

O mapa e as seçóes geológicas produzidos neste estudo apresentam uma nova perspectiva da distribuiçáo do registro cenozoico na regiáo da bacia de Volta Redonda, bem como de suas principais estruturas controladoras, vinculadas tanto ao estágio rifte quanto aos estágios de deformação neotectônica. Desta forma, a regiáo da bacia de Volta Redonda passa a apresentar um mosaico de ocorrências descontínuas e de depocentros de idade paleogênica e quaternária.

A contiguidade e correspondência de aspectos tectônicos e estratigráficos entre as áreas do graben de Casa de Pedra, graben de Dorândia, área de Vargem Alegre, área de Jardim Amália e graben da Usina, permite vinculá-las a um mesmo sistema de depocentros conectados durante o Paleógeno, definindo, portanto, a bacia de Volta Redonda stricto sensu.

Da mesma forma, o setor oeste, definido pelo graben de Colônia Santo Antônio, graben do Rio do Bananal e área do Cafundó teria se originado, durante o Paleogeno, como uma calha deposicional única e isolada, sendo limitada ao leste pela Zona de Transferência de Barra Mansa.

Os resultados indicam que os registros da Formaçáo Ribeirão dos Quatis teriam se depositado anteriormente ao estágio Rifte, preferencialmente sobre áreas periféricas àquelas que se instalaram os principais depocentros paleogênicos. Adicionalmente, também não se descarta a hipótese de esta unidade possuir idade mais antiga que a admitida (Paleogeno inicial). Desta forma, os registros desta unidade náo foram incluídos no contexto da bacia de Volta Redonda stricto sensu.

Ao estarem todos estes depocentros e demais ocorrências isoladas ao longo de um mesmo trend estrutural, a abrangência da região da bacia de Volta Redonda é aqui redefinida com dimensóes em torno de $40 \mathrm{~km}$ ao longo de seu eixo principal, de direção NE-SW e, aproximadamente, $10 \mathrm{~km}$ ao longo de seu eixo transversal, de direção NW-SE.

Quanto à evolução paleogênica da região da bacia de Volta Redonda, são admitidos pelo menos três estágios tectônicos distintos. Cada um destes sendo representado por uma tectonossequência limitada por discordâncias erosivas.

O primeiro estágio, definido como Pré-rifte, corresponderia à geração de fraturas e falhas precursoras à abertura deste segmento do RCSB e deposição da tectonossequência mais antiga, representada pela unidade litoestratigráfica Formaçáo Ribeirão dos Quatis. Esta tectonossequência vincula-se ao registro de um sistema fluvial entrelaçado de alta energia, fluindo em calhas relativamente estritas e rasas, de direção predominante NE-SW, e fortemente controladas por tais sistemas de fraturas e falhas precursoras ao estágio rifte. Considerando-se sua distribuição espacial e relaçôes estratigráficas com as demais unidades, considera-se que os principais sítios deposicionais da Formaçáo Ribeirão dos Quatis, a exemplo da área de Belmonte, tenham se comportado como altos estruturais quando da instalação do estágio Rifte, mantendo, desta forma, tais registros fora dos depocentros paleogênicos.

O estágio Rifte foi subdividido em duas fases, sendo a fase Rifte I a mais importante em termos de abertura e preenchimento sedimentar/vulcânico, e a fase Rifte II responsável pelos pulsos tectônicos finais e colmatação dos depocentros paleogênicos.

A fase Rifte I está relacionada à tectonossequência representada pela Formaçáo Resende, que corresponde a um registro de sistema fluvial entrelaçado, com desenvolvimento de amplas planícies lamosas e arenosas em direção às bordas flexurais dos depocentros, e sistemas de leques aluviais junto às suas bordas de falha principais. A este estágio também se atribui o vulcanismo basanítico (Basanito Casa de Pedra), que tem sua provável origem vinculada aos momentos de máximas taxas de estiramento deste setor do RCSB.

A fase Rifte II está relacionada a uma nova tectonossequência, representada pela Formaçáo Pinheiral, que corresponde a um sistema fluvial entrelaçado, com possível formação de corpos lacustres restritos. Pelas características das associaçôes faciológicas desta tectonossequência, considerase que fase Rifte II tenha tido taxas de subsidência relativamente menores que a fase Rifte I.

Desta forma, propóe-se para a regiāo de Volta Redonda uma analogia ao modelo de Gawthorpe \& Leeder (2000), que estabelece diferentes estágios de bacias extensionais, enfatizando a propagação e conexão dos sistemas de falhas normais que controlam a geraçáo, coalescência e preenchimento sedimentar de grabens, além do controle dos sistemas de drenagens. Assim, o momento de máxima atividade tectônica da regiâo da bacia de Volta Redonda (deposição da Formação Resende) corresponderia ao estágio 
intermediário (interaction and linkage stage) de Gawthorpe \& Leeder (2000), onde há a conexáo parcial entre sistemas de falhas de geraçóes distintas e também coalescência parcial dos principais depocentros.

A atual distribuição dos depocentros da região de Volta Redonda teria sido condicionada pela atuação dos sucessivos eventos neotectônicos de deformação, gerando altos estruturais e reativando estruturas pretéritas, o que teria promovido a segmentação de áreas contínuas. Ao evento de distensão NW-SE holocênico (E2), atribui-se a geração dos principais depocentros quaternários, como os grabens da Usina e do
Rio do Bananal, e demais ocorrências aluviais expressivas ao longo de trends NE-SW.

\section{AGRADECIMENTOS}

Os autores agradecem ao CNPq e ao PROAP-CAPES (PPGL/UFRJ) bem como ao Departamento de Geologia da UFRJ pelo fornecimento de recursos e infraestrutura necessário ao desenvolvimento deste estudo. Os autores também agradecem os valiosos comentários e sugestôes dos revisores do BJG.

\section{REFERÊNCIAS}

Amador E.S. \& Castro M.I.B. 1976. Depósitos neocenozóicos da Bacia de Volta Redonda, RJ. In: $29^{\circ}$ Congresso Brasileiro de Geologia. Ouro Preto, Anais, v. 1, p. 307-327.

Bezerra FHR., Fonseca V.P., Vita-Finzi C., Lima-Filho F.P., Saadi A. 2005. Liquefation-induced structures in Quaternary alluvials graves and gravelly sediments, NE Brazil. Engineering Geology, 76:191-208.

Carmo I.O. 1996. Análise estratigráfica de depósitos pleistocênicos no Médio Vale do Rio Paraiba do Sul (SP/RJ). MS Dissertation, Instituto de Geociências, Universidade Federal do Rio de Janeiro, Rio de Janeiro, 141 p.

ESRI. ArcGIS ${ }^{\circledR} 9$ - ArcMap ${ }^{\text {TM }}$ Tutorial. 1999. Disponível em: <http:// web-facstaff.sas.upenn.edu/ dromano/classes/gis/files/Getting_ Started_with_ArcGIS.pdf >. Acesso em: jul. 2011.

Faulds J.E. \& Varga R.J. 1998. The role of accommodation zones and transfer zones in the regional segmentation of extended terranes. In: Faulds J.E. \& Stewart J.H. (eds.) Accommodation Zones and Transfer Zones: The Regional Segmentation of the Basin and Range Province. Geological Society of America Special Paper 323, Boulder, Colorado.

Gawthorpe R.L. \& Leeder M.R. 2000. Tectono-sedimentary evolution of active distensional basins. Basin Research, 12(3-4):195-218.

Heilbron M., Pedrosa-Soares A.C., Campos Neto M.C., Silva L.C., Trouw R.A.J., Janasi V.A. 2004. A Província Mantiqueira. In: Mantesso-Neto V., Bartorelli A., Carneiro C.D.R., Brito Neves B.B. (eds.). Geologia do Continente Sul-Americano: Evolução da Obra de Fernando Flávio Marques de Almeida. São Paulo, Editora Beca, p. 203-234.

Instituto Brasileiro de Geografia e Estatística - IBGE. 2006. Projeto $R J-25$, Levantamento aerofotogramétrico do Estado do Rio de Janeiro. Escala 1:25:000. Rio de Janeiro, Instituto Brasileiro de Geografia Estatística - IBGE, Diretoria de Geociências - DGC/Coordenação de Cartografia - CCAR. Disponível em: <http://downloads.ibge.gov.br/ downloads_geociencias.htm>. Acesso em: ago. 2011.

Melo M.S., Riccomini C., Campanha G.A.C., Mioto J.A., Almeida F.F.M., Hasui Y., Ponçano W.L., Gimenez A.F. 1983. Estudos geológico-tectônicos na Bacia de Resende (RJ) e sedimentos terciários de Volta Redonda (RJ) e Bacia de Taubaté (área de Cruzeiro-SP). Relatório 17.737, IPT, São Paulo, 124 p.

Negrão A.P. 2014. Evolução tectonossedimentar e deformação rúptil cenozoica da região da bacia sedimentar de Volta Redonda (Segmento Central do Rifte Continental do Sudeste do Brasil, RJ). PhD Thesis, Instituto de Geociências, Universidade Federal do Rio de Janeiro, Rio de Janeiro, 249 p.
Padilha A.L. \& Vitorello I. 1992. Investigações geoelétricas nas bacias de Volta Redonda e Resende. In: $37^{\circ}$ Congresso Brasileiro de Geologia. São Paulo, Bol. Resumos Expandidos, v.2, p.403-404.

Ramos R.R.C. 1997. Estratigrafia da sucessão sedimentar terciária da Bacia de Resende, entre Resende e Quatis (RJ), com ênfase na caracterização das litofácies, ciclicidade e paleocorrentes. MS Dissertation, Instituto de Geociências, Universidade Federal do Rio de Janeiro, Rio de Janeiro, 208 p.

Ramos R.R.C. 2003. Sistemas aluviais terciários da Bacia de Resende, Estado do Rio de Janeiro, Brasil: análise de fácies e revisão estratigráfica. PhD Thesis, Instituto de Geociências, Universidade Federal do Rio de Janeiro, Rio de Janeiro, 221 p.

Ramos R.R.C., Ávila C.A., Vasconcelos P., Thiede P., Vasques F.S.G., Rocha F.M. 2008. Magmatismo meso-cenozóico na região das bacias de Resende e de Volta Redonda. In: 44 Congresso Brasileiro de Geologia. Curitiba, Anais, p. 559, CD-ROM

Ramos R.R.C., Mello C.L., Sanson M.S.R. 2006. Revisão estratigráfica da bacia de Resende, Rift Continental do Sudeste do Brasil, Estado do Rio de Janeiro. Geociências, 25(1):59-70.

Ramos R.R.C., Sanson, M.S.R., Mello, C.L. 2005. Novos afloramentos de rochas vulcânicas no grábens da Casa de Pedra, Bacia de Volta Redonda, Estado do Rio de Janeiro. In: 9 o Simpósio de Geologia do Sudeste. Niterói, Bol. Resumos, v.1, p. 48.

Riccomini C. 1989. O Rift Continental do Sudeste do Brasil. São Paulo, PhD Thesis, Instituto de Geociências, Universidade de São Paulo, São Paulo, 256 p.

Riccomini C., Sant'Anna L.G., Ferrari A.L. 2004. Evolução geológica do Rift Continental do Sudeste do Brasil. In: Mantesso-Neto V., Bartorelli A., Dal Ré Carneiro C., Brito Neves B.B. (eds.). Geologia do Continente Sul-Americano: Evolução da Obra de Fernando Flávio Marques de Almeida. São Paulo, Editora Beca, p. 383-405.

Sanson M.S.R. 2006. Sistemas deposicionais aluviais e tectônica cenozóica na região de Volta Redonda (RJ) - Rift Continental do Sudeste do Brasil. MS Dissertation, Instituto de Geociências, Universidade Federal do Rio de Janeiro, Rio de Janeiro, 151 p.

Sanson M.S.R., Ramos R R.C., Mello C.L. 2006. Bacias Sedimentares Brasileiras - Bacia de Volta Redonda. Phoenix, 88:1-6.

Arquivo digital disponível on-line no site www.sbgeo.org.br 